\title{
ПРИЗРЕНИЕ ДЕТЕЙ В ВОСПИТАТЕЛЬНЫХ ДОМАХ
}

\author{
НИКОЛАЙ ЯБЛОКОВ
}

Воспроизводится работа Николая Викентьевича Яблокова (1845-1904 г2.), опубликованная им в 1901 году и удостоенная похвального отзыва на первом конкурсе на соискании премии Императрицы Александры Федоровны. Поводом, побудивиим Н.В. Яблокова написать данные очерк, стало, в том числе, обрашение внимания императора Александра III на высокую смертность детей в Московском и СанктПетербургском Воспитательных домах и, как результат, последовавшие значительные изменения $в$ правилах функиионирования этих Воспитательных домов (Указ 1891 г.).

Вначале Н.В. Яблоков обращуается к истории отношения государства и общества к вытравливанию плода, детоубийству и подкидыванию незаконнорожденных детей в период, предшествующий созданию первого воспитательного дома в Милане в 767 году; а затем подробно останавливается на развитии воспитательных домов и тайных приемных корзин («tоиг») в католической Европе (в протестантских странах открытие воспитательных домов признавалось безнравственным).

Большая часть очерка посвящена организаџии помощи сиротам и незаконнорожденным детям в России в «сиропитомиах», «сиропитомских госпиталях», создававшихся при церквях вначале по частной инициативе, а позднее - по поручению Петра I, и наконец в учрежденном манифестом Екатерины II в 1763 году первом Воспитательном доме в Москве, а в 1771 году - втором в Санкт-Петербурге. Н.В. Яблоков подробно рисует картину функиионирования воспитательных домов, в том числе правил и особенностей приема и призрения в них детей. Отельное внимание уделяется положительным и отрицательным сторонам явного и тайного приема младенцев (до 1891 г. прием в Воспитательнье дома был тайныци).

Н.В. Яблоков закончил медицинский факультет Московского университета, доктор медицины, работал врачом в грудных отделениях Московского Воспитательного дома и главным врачом в Софийской детской больнице (ныне - Детская городская клиническая больница № 13 имени Н. Ф. Филатова); активно занимался организациинными вопросами, связанными с охраной здоровья детей и их социальной защчитой.

Ключевые слова: Воспитательный дом, сироты, незаконнорожденные дети, подкидыши, младенческая смертность.

В конце 1888 года Государем Императором Александром III было обращено внимание на значительную смертность детей в Воспитательных домах и было поручено Опекунскому Совету озаботиться изысканием мер децентрализации двух наших столичных воспитательных домов, в видах отвлечения или уменьшения числа ежегодно отдаваемых туда детей.

Это указание повлекло за собой обсуждение, сопровождаемое собранием Петербургского и Московского Присутствий Опекунского Совета, установление системы явного приема детей в воспитательные дома и ограничение района благотворения этих воспитательных домов столичными губерниями.

НикОЛАЙ ВИКЕНТЬЕВИЧ ЯБЛОКОВ (1845-1904).

ЯБЛОКОВ Н.В. (1901). ПРИЗРЕНИЕ ДЕТЕЙ В ВОСПИТАТЕЛЬНЫХ ДОМАХ / Т ТРУДОВАЯ ПОМОЩЬ: МАРТ, АПРЕЛЬ И ИЮНЬ. 
Разработкой практического разрешения вопроса о преобразовании Воспитательных домов в указанном направлении занялась особая комиссия из восьми почетных опекунов, представившая проект новых правил приема в Воспитательные дома и возврата из них детей. Правила эти как временные были введены в действие с 1 июля 1891 года, а в 1894 году с несущественными изменениями утверждены как постоянные, на основании которых оба столичные Воспитательные дома - Петербургский и Московский - ныне и функционируют.

Эти новые правила, изменившие в корне 130-летнюю функцию наших Воспитательных домов - тайный прием детей на явный - не перестают вызывать в обществе различные толки и недоразумения, в основе которых лежит полное незнакомство не только с сущностью последовавших изменений правил приема детей, но и с самой задачей наших домов призрения, историей их возникновения, современной их жизнью и результатом деятельности.

Близкое знакомство с деятельностью наших столичных Воспитательных домов позволяет нам в предлагаемом очерке представить читателю картину современного строя этих благотворительных учреждений. Первую главу мы посвящаем историческому обзору возникновения и развития идеи призрения детей, от воспитания которых отказываются их родители.

\section{I}

Идея Воспитательных домов, или, что то же, призрения детей, покинутых своими родителями, возникла вместе с торжеством христианского учения, основанного на любви к ближнему с ее милосердием и состраданием. Теперь, когда всякий случайно найденный трупик новорожденного ребенка вызывает составление полицейского протокола и дальнейшее судебное следствие, трудно даже себе представить то бессердечие, ту жестокость, то варварство по отношению к детям, какие существовали и были терпимы у древних народов. Детоубийство у них не только не каралось законами, а в известных случаях, напротив, даже предписывалось ими.

Политические интересы заставляли желать, чтобы граждане были физически сильны, способны в рядах мужественного войска защищать свое отечество. Отсюда греческий закон Ликурга, предписавший особым судьям производить экзамен на здоровье каждому новорожденному мальчику, и не выдержавшего такого экзамена, оказавшегося слабым по телосложению или уродливым, бросали с Тайгетской скалы. Кроме бесполезности для государства, в таком ребенке предусматривали возможность вырождения расы, в случае если бы такие слабые и уродливые дети, оставаясь в живых, производили хилое потомство.

Экономические расчёты, страх излишнего размножения народонаселения выразились в древних греческих законах (законы Солона), предоставляющих отцам полную свободу располагать жизнью и смертью своих детей, подкидыванием их и продажею в рабство. Проникнутые чувством государственного долга, отцы семейств зорко смотрели за численностью своей семьи и широкой рукой подкидывали или убивали непрошено 
явившихся на свет детей. В особенности девочек, комплект которых благоразумно определялся в одну первую девочку, так как в избытке именно этого пола и коренился страх правительства за несоответствующий прирост народонаселения, содержание которого тяжелым бременем ложилось на истощенную беспрерывными войнами государственную казну.

В свою очередь и религия не отставала в кровавой расправе с ни в чем неповинными беззащитными малолетками. Устами жрецов боги требовали жертвоприношения детей и, например, Сатурн, обиженный жертвоприношением одних лишь детей рабов, умилостивлялся приношением ему за раз в жертву двухсот знатных и трехсот незнатных законных детей. В древней Персии зарывали в землю живых детей знатных родителей не только в честь богини, но и в честь какого-либо умершего общественного деятеля.

Выдающаяся жестокость к детям у Римлян объясняется развращенностью их нравов и привычкою к кровавым зрелищам в цирках.

Здесь мы встречаем на первом плане страшное отцовское право (patria potestas), право жизни и смерти над своими детьми, независимо от их возраста, право продажи их в рабство, заключения в темницы и т.п. Если отец не поднимал с пола положенного акушеркой к его ногам новорожденного ребенка и отворачивался от него, то последнего тотчас убивали или подкидывали на городской рынок у columna Lakturia или на берег Велабрского озера. Здесь ребенка, если он не успевал попасть в зубы бродячих собак, ожидали руки покупщиков невольников, или еще более грязные руки других субъектов, которые заботливо воспитывали из такого подкидыша гладиатора, проститутку или, к ужасу и отвращению человечества, изуродованного нищего, то несчастное существо, вид которого должен был возбуждать усиленное сострадание граждан и гражданок, влекущее за собой избыток милостыни, как награду за удачное искалечение различных членов этого несчастного существа, в глазах закона представлявшегося только рабом (так как все подкидыши - рабы) и к тому же не приносившего самой республике никакого вреда. Проявлявшееся в редких случаях естественное материнское чувство заставляло римлянок различными женскими хитростями обходить жестокий отцовский приговор и прибегать к средству спасения жизни своего новорожденного подкидыванием его в лесные дебри, в расчете на внимание к нему какой-либо жалостливой волчицы, милостиво принимавшей подкидыша в свое семейство и становившейся его кормилицей. Легенда о возможности такого внимания связана с именем основателей Рима, подкидышей Ромула и Рема, и вероятно построена на случаях воспитания таких подкидышей каким-либо сострадательным лицом, или самой же матерью, тайно устроившей их воспитание.

Правительственная власть не отставала от отцовской; кроме целиком перенесенного из Греции закона Ликурга о новорожденных, дело дошло до разрешения убивать и взрослых детей. В Карфагене на особых судей в сенате возложена была обязанность признавать законность происхождения ребенка сходством его с отцом по достижении двухлетнего возраста и, признанных незаконными, разрешалось убивать или подкидывать. В одном случае правительство силою отняло у отца болезненного сына, которого он с нежностью воспитывал, и бросило его в море. Так серьезно смотрели за неуклонным исполнением закона, преследовавшего предупреждение вырождения расы. 
Если детоубийство разрешалось, поощрялось или даже предписывалось законами, то конечно законы эти не преследовали греческих и римских кокеток за вытравление плода; а это было, во-первых, в большой моде, как средство сохранить по возможности дольше свою красоту и грацию, а с ними и все выгоды, и, во-вторых, как исполнение законных, основанных на финансовых расчетах, приказаний мужей ограничиваться наличным числом детей в семействе.

Насколько такое варварское отношение к детям было обыденным, вкоренившимся в нравы общества, видно из дошедших до нас мнений знаменитых философов, поэтов и писателей того времени. Плутарх не решается сам ответить себе: как следует смотреть на ребенка в утробе матери, как на живое существо или нет; сомнение его в утвердительном смысле разрешает один лишь Платон, в то время как Эмпедокл, Диоген и стоики отрицают существование души и жизни у материнского плода. Тот же Плутарх считает государственною обязанностью убивать неправильно развитого ребенка, а детоубийство из-за бедности считает за справедливое отцовское чувство: что за охота отцу видеть своих детей в нужде. Платон, кроме убийства слабых и плохо сложенных детей, стоит за убиение всех, родившихся от престарелых родителей (отца за 50 и матери за 40 лет). Для своей фантастической республики он, чтобы создать лучшую расу, проектирует свободные, безбрачные отношения со строго определенным подбором, низводя, таким образом, людей на степень скотов. Аристотель требует строго определять число детей для каждого семейства, лишние дети должны быть подкидываемы, а где подкидывание не практикуется, там матери должны в таких случаях производить выкидыш. По учению Сенеки, в удалении из среды своей известных членов общества должно руководиться не чувствами, а разумом; надо, говорит он, немедленно утопить ребенка, если он урод или слабосильный. Он же высказывает сомнение, стоит ли тратить заботы и средства вообще на воспитание ребенка в виду неизвестности и риска в результатах такого воспитания. Все древние писатели в своих творениях в той или другой форме констатируют совершавшиеся факты детоубийства и подкидывания, и не встречается ни одного поэта, писателя или историка, который хотя бы одним словом обмолвился против детоубийства или в пользу сострадания к подкидышам.

Подтверждением зависимости от политико-экономических и религиозных условий обычая не утруждать себя заботою о воспитании всех рождавшихся детей являются счастливые исключения защиты детей законами в древнем Египте, у персов и евреев. При дешевизне прожития в плодоносных равнинах Египта и желании возможно большего размножения народа, египетские цари издавали законы, каравшие детоубийц и запрещавшие подкидывание, хотя из тех же политических расчетов здесь проявилось жестокое избиение израильских младенцев мужеского пола. С введением ислама в Персии прекращаются жертвоприношения детей, а ради желанного прироста народонаселения запрещается убиение детей, и выдаются даже премии плодовитым семьям. Обетование населить всю землю заставляло евреев крайне заботливо относиться к жизни каждого ребенка, и не было большего несчастья для еврейской женщины, чем бесплодие. Мы встречаем здесь обстоятельные законы, оберегающие ребенка еще в утробе его матери, а ее самой во время беременности; нет недостатка и в толковых гигиенических советах, охотно исполняемых еврейками, из которых каждая верит в возможность происхождения 
от нее ожидаемого Мессии. Насколько преступления против детей представлялись немыслимыми среди этой нации, видно из того, что в строгом против всякого убийства законе Моисея даже не упоминается о каком-либо наказании за подобные преступления против детей.

Но такие островки гуманного отношения к детям среди моря жестокосердия древних народов были также малочисленны, как теперь малочисленны обратные случаи. К стыду современного человечества, и в настоящее время у некультурных народов детоубийство еще процветает, находясь в зависимости от суеверных обычаев или крайней бедности. По словам миссионеров, в западной Африке, на островах Рук, Мадагаскаре и в других местах бросают на съедение собакам, топят и душат веревкой малюток, имевших несчастие родиться с пороками развития или родившихся в непоказанные, считающиеся несчастливыми дни, среду, пятницу или в последнюю неделю каждого месяца, а то так и в течение целого марта и апреля, как это практикуется племенем Малгаши.

При наличности в древнем мире политеизма и господства отмеченных нами исключительных взглядов на ребенка не могло быть и речи о чем-либо похожем на приюты для детей, на воспитательные дома. Но когда люди пресытились, наконец, своим варварством, жестокостью и развращенностью и стали вслушиваться в слова учения Христа, когда свет этого учения озарил их ум и наполнил сердца любовью, милосердием и состраданием к ближнему, участь беззащитных малюток изменяется. Конечно, такой перемене суждено было совершиться далеко не так быстро, как того искренно желали проповедники христианского учения. Они должны были столкнуться с веками укоренившимся пренебрежением к ребенку, с еще функционировавшими государственными законами и, наконец, с бедностью народа, этой вечной причиной, плодящей бесприютных детей.

По-видимому, стройному развитию защиты детей более всего препятствовали вкоренившиеся в нравы вчерашних язычников жестокосердие и безразличие к маленьким существам. Впрочем, много удивляться этому не приходится. В то время как за нами были уже века исповедания Христова учения, мы были свидетелями невообразимых жестокостей, практиковавшихся у наших собратьев. Стоит вспомнить прославившуюся в Испании религиозную инквизицию, или политическую в форме различных дыб и застенков восемнадцатого столетия, кнута и шпицрутенов прошлого столетия, не говоря уже о помещичьей, бурсацкой и других инквизициях, которые у нас на памяти, равно как о розге, защищаемой и доныне некоторыми руководителями даже общественного мнения. Нечего, повторяем, удивляться, если с введения христианства прошли века, прежде чем представителям учения удалось обеспечить права на жизнь рождавшимся детям и найти возможность устроить воспитание тем из несчастных, которых родители бросали на произвол судьбы.

Неустанная проповедь сострадания к детям Св. Иустиниана, Варнавы, Луки на западе, Климента, Зосимы, Василия Великого на востоке нашла отклик и покровительство со стороны императоров первых веков христианства. Один за другим издаются ими законы, воспрещающие продавать своих законных детей (Александр Север, Септимий Север, Каракалла), предписывающие отцам воспитывать всех детей, сколько бы их ни родилось 
(Деоклетиан). Чтобы защита детей от произвола родительской власти не оставалась гласом вопиющего в пустыне, император Константин в 318 году издал закон, каравший смертной казнью отцов, поднявших руку на своих детей; закон этот был повторен его преемниками, братьями Валентом и Валентинианом, а также сыном последнего Грацианом. В своем участии к судьбе маленьких своих подданных Константин впервые делает попытку организовать дело благотворения; он издает указ о безотлагательной из средств государственной казны, а частично из его личной, денежной помощи родителям, по своей бедности не имеющим возможности воспитывать детей. К сожалению, в виду крайнего истощения государственной казны, ему скоро пришлось отказаться от такой благотворительной миссии.

Хотя законы Константина, Валента и Грациана обязывали родителей воспитывать всех своих детей и подкидывание законных детей запрещалось, но таковое конечно продолжало существовать, и подкидыши по тем же законам превращались в рабов тех лиц, которые их призревали. Только в VI веке личность подкидыша объявляется свободной. Принцип - человек принадлежит себе самому - находит место в кодексе императора Юстиниана, по которому подкидыш не должен считаться собственностью того, кто его приютит, равно как и того, кто его бросил; он - свободный гражданин, имеющий право даже приобретать имения. По этому кодексу самый акт подкидывания считается хуже обыкновенного смертоубийства, так как производится над существами слабыми и беспомощными, а потому виновные должны подлежать самому строгому наказанию. В указе того же Юстиниана префекту и архиепископу Фессалонику предписывается, под страхом за неисполнение штрафа в пять фунтов золота, оказывать возможную помощь (на государственный или церковный счет) всем подкидышам.

К сожалению, нельзя найти указаний, состоялось ли и в какой именно форме проектированное Юстинианом устройство домов призрения для подкидышей.

Законы о правах подкидышей, изданные Юстинианом, с небольшими изменениями и дополнениями действовали до самого падения Византийской империи.

У народов, утвердившихся на развалинах Западной Римской империи, личность ребенка пользовалась большим покровительством законов. Так, у вестготов за вытравление плода закон наказывал виновного в этом преступлении смертной казнью, а решившаяся на это мать наказывалась отдачею в рабство, если же она была раба, то подвергалась 200 ударам кнута. За убийство же вполне сформированного, хотя бы еще и не родившегося ребенка, всякий подлежал смертной казни, или в виде особой милости - выкалыванию глаз.

По баварскому уложению за участие в вытравлении плода полагалось 200 ударов кнута и смертная казнь, в случае, если подвергавшаяся вытравлению мать умирала от этого. По салическим законам за убийство беременной женщины полагался штраф в 700 солидов, убийство ребенка до 8 лет облагалось штрафом в 200 солидов, за убийство женщины, способной производить детей - 200 солидов, за вытравление плода - 62 солида. По германским законам за вытравление плода, оказавшегося девочкой, штраф был вдвое более, чем за мальчика. В законах этих народов подкидывание ненаказуемо; оно не считается преступлением, встречаются лишь детальные определения суммы вознаграждения воспитателю при притязаниях родителей на возвращение себе подкинутого 
ребенка. Несмотря на то, что жизнь каждого ребенка была так обстоятельно защищена законами, участь большинства их, в виду страшной бедности, господствовавшей у пришельцев в Европу, была очень плачевна. Торговля детьми была очень распространена, продажа их на рынках производилась вполне открыто наравне с домашними животными.

Независимо от императорских законов в деле защиты детей настойчиво проявляли свою деятельность представители церкви. На каждом вселенском соборе уделялось время на рассмотрение различных вопросов, касавшихся защиты детей, и собор делал по ним постановления. В этих постановлениях отражалось влияние воззрений, господствовавших в данное время на личность подкидыша. Так, в виду частых пререканий о праве на подкидыша между лицом, его приютившим, и родителями или родственниками, на одном из соборов было установлено предоставить церкви утверждать права на подкидышей. Нашедший подкидыша обязывался принести его в церковь, где в ближайшее воскресенье объявлялось во всеуслышание о таком случае; если в течение 10 дней после такого объявления никто не заявит на него своих родительских прав, то лицу, предъявившему подкидыша, выдавалось за церковною печатью удостоверение о праве собственности на такого подкидыша, служившее гарантией от всяких притязаний и исков со стороны родителей. Если же в течение этого десятидневного срока объявлялись родители подкидыша с свидетельскими удостоверениями, то этот последний передавался им; они же, как виновные в преступлении-подкидывании, подвергались наказанию в форме церковного покаяния. Сроки покаяния за подкидывание (равно как за детоубийство или вытравление) на многих вселенских соборах подвергались пересмотрам и колебались от 7 до 10 лет.

С целью предупредить убийство и подкидывание незаконнорожденных детей, на Руанском соборе было постановлено устраивать при церквах мраморные чаши, куда матери могли бы класть своих незаконных детей. Забота о таких церковных приемышах возлагалась на приходских священников: их обязывали приискивать для них среди своих прихожан воспитателей, за которыми такие подкидыши и закрепощались. Дети, никем не взятые, оставались при церкви, воспитывались здесь и впоследствии становились собственностью - рабами этой церкви.

К упомянутой выше продаже детей на рынках представители церкви, конечно, также не могли оставаться равнодушными; с кошельком в руках они являлись на рынки и покупали этот недорогой товар, с тем, чтобы освободить их от угрожавшего им рабства, воспитать их в лоне Христианской церкви. Очевидно, руководящей идеей инициаторов воспитания подкидышей при церквах было увеличение ими последователей, а впоследствии и проповедников Евангелия. В этих церковных монастырских убежищах для детей мы должны видеть прототип будущих воспитательных домов, в основе которых лежит, если не вполне, то главным образом, забота о незаконных детях.

Первым таким общественным учреждением является воспитательный дом, устроенный в 787 году в Милане Архиепископом Датеем. Возмущенный частыми случаями бросания самими матерями своих незаконных детей в канавы, навозные кучи, реки и т.п., Датей «ради спасения своей души и душ своих сограждан» приказывает, «чтобы купленный им близ церкви дом служил впредь убежищем для незаконных детей; чтобы каждый подкинутый в церковь ребенок был тотчас надзирателем убежища поручен заботам и уходу 
особым платным кормилицам.... После обучения детей ремеслу, по достижении ими 8-летнего (?) возраста, они свободно без всякого обязательства могут оставить приют и жить, где хотят». Только через 200 лет после этого первого воспитательного дома был открыт в Европе второй воспитательный дом - в Бергамо, также при одной из церквей; затем в 1041 г. в Лайбахе гражданином этого города, Петром Берлахом, за свой собственный счет был учрежден сиротский дом с правом принимать туда и подкидышей. Вслед за этими первыми воспитательными домами во всех государствах Европы по инициативе частных лиц один за другим открываются приюты для бедных детей, сирот и подкидышей. C XVI века начинает проявляться государственная забота о таких детях; в Италии, Испании, Франции особыми указами забота эта поручается монастырям и церквам, а затем и муниципалитетам.

\section{II}

Мы не будем шаг за шагом следить за развитием дела призрения подкидышей в различных государствах и ограничимся лишь изложением в общих чертах современного положения этого дела в Европе.

В практикуемых способах призрения детей государства протестантские и католические резко отличаются друг от друга. В то время как католические Италия, Испания, Португалия, Франция, Бельгия, и Австрия дали более или менее широкое развитие системе воспитательных домов, протестантские Англия, Германия и Швейцария отказались от этого способа призрения детей, находя для общества безнравственным существование приютов для незаконнорожденных детей: такими приютами родители отстраняются от своего естественного долга. Законы этих трех государств разрешают ребенку, или вернее матери его, предъявлять иск об отцовстве (Vaterschaft). Немногочисленные городские, общественные или благотворительные учреждения ограничиваются призрением сирот или тех детей, родители которых находятся в тюрьмах, больницах и т.п. Что же касается незаконнорожденных, то воспитание их возлагается на мать и отца, в случае же их бедности на родителей матери или отца ребенка. Городские и общественные учреждения берут на себя заботу о незаконнорожденном ребенке только на время розысков (законным порядком) отца, если притом мать по бедности своей действительно не может воспитывать ребенка у себя. Одно несомненно, что эта система призрения детей в сравнении с системою воспитательных домов значительно дешевле; имеет ли она за собой другие преимущества, мы увидим из дальнейшего изложения.

На родине воспитательных домов - в Италии - до сих пор удержался тип призрения детей, положенный Датеем в основу учрежденного им первого (Миланского) воспитательного дома. Многочисленные, содержимые отчасти на специальные средства, отчасти на средства провинций и общин, воспитательные дома призревают незаконнорожденных детей, подкидышей, равно как сирот и законных (бедных), причем на эту последнюю категорию детей идут средства общин. Хотя здесь и нет одного, общего для всех заведений, устава, но всеми ими практикуется система тайного приема детей, т.е. принимается всякий принесенный ребенок, без всяких документов, без всяких расспросов, чей он, откуда и по какой причине отдается. По этой, от древних времен унаследованной, 
системе считается нескромным по отношению к тайне матери взглянуть даже в лицо приносящему ребенка; с этою целью у стены приемной приспособляется особой формы корзина $\left(\right.$ tour $\left.^{l}\right)$, которая при помощи механизма перевертывается внутрь приемной, давая при этом знать (звонком) о появлении в доме нового приемыша. В последнее время, впрочем, и в Италии, стране, где был изобретен «tour», отказываются от этой системы приема. Общины одна за другой закрывают «tour», заменяя его открытым приемом с соблюдением все-таки тайны матери, т.е. приноситель ребенка может уклониться от ответов на вопросы о происхождении ребенка и состоянии его родителей. Особенно много «tours» остается еще в Сицилии и Неаполитанских провинциях. Из 357 общин Сицилии «tour» функционирует еще в 161. Насколько таких гостеприимных корзин было много во всем королевстве, можно судить из того, что по отчету Raseri за 1884 г. их было 659, да около 600 считаются закрытыми. Не следует смешивать эти тайные приемные корзины с воспитательными домами; заведений для призрения детей в королевстве 118, приемных же, разбросанных во многих общинах, несравненно больше; из них дети немедленно препровождаются в ближайший воспитательный дом. Во всяком случае, результатом такой широкой благотворительности при посредстве тайного приема являются громадные цифры призреваемых: свыше 130000 детей находятся на попечении всех воспитательных домов Италии, при ежегодном бюджете в 14 слишком миллионов лир.

Ни один из воспитательных домов Италии не оставляет принятого ребенка у себя: роль воспитательного дома ограничивается временным призрением ребенка, который поступает на дальнейшее воспитание в частные семьи, преимущественно крестьянские, в которых воспитывается и обучается землепашеству и ремеслам, оставаясь под попечительством воспитательного дома до 25 лет. Такой долгий срок учрежден нарочно, чтобы матери, имея в перспективе такую долгую потерю права на возвращение к ним их детей, меньше отдавали их в воспитательные дома.

Участие общин и провинций в расходах по содержанию воспитательных домов дает возможность участвовать им в издании и изменении по их усмотрению правил приема, срока пребывания ребенка в доме, вознаграждения кормилицам и воспитательницам, устройства надзора за воспитанием в деревнях и т.п. Таким образом, в одних воспитательных домах дети остаются только 1-2 дня, а в других более продолжительное время. Плата кормилицам варьирует между 10 и 18 лирами в месяц. Кормилицы, набираемые общинами для посылки их в соседние дома за детьми, получают за воспитание их от 9 до 12 лир в месяц за первый год, за детей до 2 лет 6-9 лир и т.д., постепенно убавляя до 12 лет в одних и до 15 лет в других воспитательных домах. Вознаграждение за хороший уход и обучение грамоте также различно; оно колеблется между 30 и 50 лирами; в приданое питомкам одними выдается 75, другими 100 и 200 лир. Дело надзора за воспитывающимися в деревнях тоже не имеет определенного строя; в одних случаях оно организовано при посредстве бесплатных членов особого комитета, в других - при посредстве особых чиновников-надзирателей и в третьих (в большинстве) - возложено на священников и синдиков. Очевидно, различие это зависит всецело от средств, предоставляемых данному

\footnotetext{
${ }^{1}$ Tour (фр.) - в данном случае, вращающийся цилиндрический шкаф (прим. ред.).
} 
воспитательному дому провинцией: Пьемонт и Ломбардия, ассигнующие более миллиона лир в год, могут организовать дело лучше, чем, например, Умбрия, дающая 95 000, или Сардиния, предоставляющая только 20000 лир в год.

Отсутствие однообразия в администрации, правилах и пр. отражается и на отчетности, которая, будучи в свою очередь тоже не однообразной, не дает возможности сделать какие-либо общие выводы о результатах деятельности подобных благотворительных заведений королевства.

Тип Итальянского воспитательного дома целиком был перенесен во Франщию и в общих чертах сохранился там до настоящего времени.

По особому декрету, изданному Наполеоном I в 1811 г., в различных департаментах Франции было открыто на государственный счет триста воспитательных домов. По этому декрету при каждом воспитательном доме должен был быть устроен «tour». С течением времени, когда, с одной стороны, содержание этих воспитательных домов должно было перейти на бюджет департаментов и когда, с другой стороны, чрезмерная эксплуатация такими воспитательными домами с «турами» дала себя чувствовать в непомерно увеличивавшихся расходах, многие из этих воспитательных домов по распоряжению департаментов были закрыты, а в тех, которые остались, были закрыты функционировавшие до того «tours». Закрытие «tours» распоряжением отдельных департаментских собраний вызывалось признанием за ними, как за системой тайного приема детей, условий чрезмерно большего числа питомцев, оказывавшихся на призрении в воспитательных домах. Законодательным порядком обязательное существование «тура» до сих пор не отменено. Ни одно из часто сменявшихся министерств не решилось на пересмотр закона о «турах», очевидно из опасения вызвать закрытием их увеличение детоубийств и подкидывания; притом среди депутатов всегда находятся горячие приверженцы этой отживающей системы «тайного» приема детей.

Так как теперь во Франции призрение детей, брошенных их родителями, лежит на обязанности каждого департамента, степень благоустройства этого призрения всецело зависит от средств данного департамента: располагающие большими средствами проявляют свою заботу в более широких размерах и наоборот. Там, где средств отпускается мало, там не только закрыты «tours», но и практикуются всевозможные стеснения в приеме детей. За такие скупые департаменты приходится расплачиваться гостеприимному Парижскому воспитательному дому, куда в таких случаях (по железным дорогам) спешат отправить ребенка.

В Парижский «Нospice des enfants assistés» принимаются: а) дети на временное призрение, когда родители их больны, арестованы или лишены временно средств воспитывать своих детей (les enfants en dépôt), в) незаконнорожденные, подкидыши, бесприютные (abandonnés) и сироты, это собственно assistés; дети этой категории возвращаются родителям только в исключительных случаях, с уплатою потраченных на них расходов и с) нравственно испорченные дети.

C уничтожением «тура» в Парижском воспитательном доме прием ребенка производится в особой приемной и обставлен, как объявлено, абсолютным секретом; 
абсолютным лишь в смысле серьезной ответственности (за выдачу секрета) лиц, стоящих у приема. Впрочем, организованный прием детей нельзя назвать и открытым, так как, хотя дежурная сестра милосердия и задает некоторые вопросы о принесенном ребенке: о его происхождении, времени рождения (требование документа), средствах его родителей, но ответы на все эти вопросы не обязательны. Если ребенка приносит сама мать, то ей обязательно указывается, что, отдавая ребенка в воспитательный дом, она лишается возможности видаться с ним, знать, где он будет воспитываться, и только раз в каждые три месяца может получить сведения, жив ли он или умер. Кроме того, ей предлагается, взамен приема ее ребенка в воспитательный дом, ежемесячная денежная помощь, если она будет вскармливать ребенка у себя на дому. Как на главный принцип приема, указывается обеспечение ею во что бы то ни стало жизни ребенка и вместе с тем семейной тайны; все остальное - на втором плане.

Если принятый ребенок оказывается здоровым, его отправляют с кормилицей в деревню, слабых же оставляют в центральном доме, причем больных сифилисом или подозрительных в отношении этой болезни вскармливают искусственно. Для этого рода больных несколько лет тому назад, по инициативе ныне умершего д-pa Parrot, были устроены отдельные павильоны, с примыкающими к ним конюшнями для ослиц. По мере надобности в павильон приводится ослица, и спеленутый ребенок прикладывается к соску ослицы и таким образом питается непосредственно «живым» молоком животного, молоко которого по химическому анализу ближе всего подходит к женскому молоку. В то время как до устройства этого отделения дети-сифилитики, вскармливавшиеся коровьим молоком из рожков, умирали в громадном проценте 75-85\%, при этом кормлении процент смертности их не превышал (при Parrot) $30-40 \%{ }^{2}$.

Во избежание чрезмерной скученности детей, главным образом сирот, бесприютных и нравственно испорченных, Парижский воспитательный дом пользуется филиальным отделением Thiais, находящимся в окрестностях Парижа; впрочем и эти дети, если не будут своевременно взяты обратно из дома их родителями или родственниками, перечисляются в разряд «enfants assistés» и раздаются на воспитание в деревни.

Деревенские округа, числом 30, устроены в двенадцати более или менее отдаленных от Парижа департаментах. Управление каждым таким округом поручается инспектору, на обязанности которого между прочим лежит приглашение врача (за известное вознаграждение) посещать каждого трудного ребенка (до двухмесячного возраста еженедельно, а более старшего возраста ежемесячно, или раз в три месяца). Если врач найдет при своем посещении уход за ребенком плохим или молоко кормилицы негодным, то имеет право переменить кормилицу.

В определенные сроки инспектор посылает из своего округа кормилиц за детьми в Парижский воспитательный дом; кормилиц этих сопровождает женщина-проводник, с которою они и возвращаются обратно в округ. Являющаяся в воспитательный дом из округа

\footnotetext{
${ }^{2}$ В дальнейшем своем применении этот способ искусственного кормления потерпел фиаско, также как и многие другие подобные способы. В настоящее время этих павильонов с ослицами более не существует.
} 
кормилица должна представить удостоверение в своей благонадежности, как воспитательницы, и в том, что ее собственный ребенок достиг уже семимесячного возраста и отнят от груди, или умер. Такое требование к кормилицам теперь предъявляется во всей Франции, на основании закона, известного под именем «закона Русселя», имеющего за собой неоспоримое достоинство: он является защитником естественных прав всякого грудного ребенка на молоко своей собственной матери, из-за житейских, денежных расчетов поступавшей в кормилицы к богатым людям, а своего ребенка бросавшей на рожок или соску, способствующих преждевременной смерти. Нельзя не пожелать распространения этого гуманного закона во всех государствах, где царит кормиличный промысел.

На обязанности инспектора кроме надзора за воспитанием детей и кормилиц лежит подбор места и заработка всем достигшим 14-летнего возраста питомцам, срока, когда за них прекращается плата от воспитательного дома, и когда семья воспитательницы не может по своей бедности бесплатно продолжать содержать у себя питомца-работника. Ежемесячная плата за воспитание ребенка Парижским воспитательным домом производится довольно большая: 25 фр. до одного года, 20 фр. до двух лет, 15 фр. до трех и 10 фр. до тринадцати лет, причем все дети за это время одеваются на счет воспитательного дома. Кроме того, за хороший уход грудного ребенка выдается вознаграждение по 6 фр. за каждые три месяца в течение первого года. За обучение грамоте выдается 50 фр. воспитательнице, 40 фр. учителю и 10 фр. вносится на имя воспитанника.

Пожертвованное в 1886 г. одним полковым священником владение в Алжире, с целью устройства в нем земледельческой школы для питомцев, даст возможность правительству из колонизированных там молодых питомцев образовать собственников, обучившихся предварительно в школе земледелию и виноделию.

Число призреваемых Парижским воспитательным домом питомцев (в доме и округах) составляет внушительную цифру (для 1888 г.) - тридияать две с половиною mысячи ${ }^{3}$, с годовым расходом на них около восьми миллионов франков. Все же воспитательные дома Франции имеют на своем попечении более 125000 питомцев, распределяющихся различно для каждого департамента: в то время как Парижский воспитательный дом имеет 32 000, Bouchées du Rhône имеет 4000 питомцев, Tarn - 293, a Haut-Rhin (Belfort) только 174.

Во многих департаментах с уничтожением «tour» стали практиковать денежную помощь матерям-девушкам, кормящим своих детей у себя дома, при чем размер такой помощи колеблется от 15 до 40 фр. в месяц, за искусственное кормление дешевле, за грудное дороже и продолжается в течение 1-1,5 лет. Эта система, по-видимому, имеет за собой будущность. Кроме того, что она обходится дешевле против воспитания ребенка в воспитательном доме, она в принципе имеет за собой развитие материнского чувства к ребенку, которое при других системах напротив уничтожается в корне, так как ребенок

\footnotetext{
${ }^{3}$ В возрасте от 1 дня до 13 лет - 21 350, от 13 лет до 21 года - 11 140. В это число не входят 8587 детей, которым оказывается помощь на дому, и 4400 нравственно испорченных детей.
} 
навсегда разъединяется с матерью. За эту же систему говорят и статистические данные, по которым процент смертности детей, воспитывающихся в округах Парижского воспитательного дома, доходит до $30 \%$, у родных же матерей на дому не превышает 17,7\%.

В то время, как Итальянские и Французские воспитательные дома, приняв к себе ребенка, не дозволяют матери знать что-либо о нем, сообщая ей только, жив он или нет, в Австрийских воспитательных домах мы встречаемся с совершенно обратной формой: здесь, напротив, привлекают, обязывают матерей не только кормить своих детей в центральных заведениях, но и воспитывать у себя в деревне, с производством за то ежемесячной платы (на одну треть меньшей). В основе такой системы лежит забота о доставлении нормального питания грудному ребенку, принятому на попечение воспитательным домом. Плата эта, впрочем, производится значительно более короткое время против других воспитательных домов: она ограничивается шестью годами. Французская система абсолютного разъединения ребенка с матерью принята ради ограничения отдачи детей в воспитательные дома: думают, что материнское чувство в некоторых случаях удержит от отдачи ребенка в воспитательный дом при условии полной разлуки с ним. В Венском и Пражском воспитательных домах прием их детей достигается практикуемым условием приема, кроме подкидышей, только детей от незаконных матерей, родивших в родовспомогательном заведении (воспитательный дом существует при родильном доме). Непродолжительное, в течение 9-10 дней, пребывание ребенка в центральном здании обставляется прекрасным содержанием и уходом с отдельной для каждого ребенка кормилицей, строгий выбор которых обеспечивается контингентом родильниц, обязанных за предлагаемые им услуги родильного дома бесплатно в течение четырех месяцев оставаться в кормилицах воспитательного дома. Здесь нет недостатка и в деревенских воспитательницах, преимущественно из наиболее бедных и отдаленных от Вены областей. Являющаяся за ребенком кормилица обязана представить удостоверение от общины о благонадежности, имении одной коровы или двух коз, от врача о здоровье и отсутствии в общине эпидемических болезней. Плата за воспитание в первый год по 6 гул. в месяц, от 2-6 лет 4 гульдена. Специального надзора за находящимися на воспитании в деревнях питомцами не организовано, надзор поручается священникам и начальству общины. Существующий штат собственных агентов - надзирателей - настолько ограничен, что они в состоянии навещать каждого отданного в деревню ребенка лишь один раз в три, четыре года. При ежегодном приеме в 7000 детей в Венском и 3000 в Пражском воспитательных домах, число всех призреваемых для первого равняется 30 000, для второго 10000.

Что касается до воспитательных домов Швеции (в Стокгольме) и Дании (в Копенгагене), то главное их отличие заключается в оплате за воспитание ребенка со стороны матерей их трудом - поступлением в бесплатные кормилицы на срок восьми месяцев, а также денежным взносом (400-500 крон) родителей, общины или благотворительных заведений (250-300 крон). Для безвозмездного воспитания остается категория детей - подкидышей, доставляемых полицией. Кроме того, отличительной чертой воспитательных домов этих государств является продолжительность - до 3 месяцев пребывания ребенка в центральном заведении, а в Бельгии (Брюссель) даже до 18 месяцев. Такой продолжительный срок пребывания под надзором администрации и врачей здесь вполне возможен, так как ежегодное число детей, поступающих на призрение, равняется 
лишь 180 в Брюссельском, 310 в Стокгольмском и 550 в Копенгагенском воспитательных домах. К этому же обязывает и неуверенность в грудном кормлении детей в деревнях, так как искусственное кормление детей в деревнях очень распространено, в особенности в Швеции и Дании.

Кроме воспитательных домов в этих двух странах за последнее время широко развивается деятельность частных благотворительных обществ, в форме семейных приютов и сельских колоний, где покинутые дети получают свое нравственное и профессиональное (земледельческое) воспитание.

Воспитательные дома Греции и Румынии представляют собой небольшие приюты, устроенные по системе тайного приема, с «туром». Ежегодное число призреваемых не превышает 250 в Афинах и 100-150 в Бухаресте. Практикуемая раздача детей в частные семьи без организованного надзора дает в результате колоссальную смертность - 58\% до годовалого возраста в Греции и 50\% до полугода в Бухаресте.

В Сербии и Черногории для незначительного числа подкидышей всегда оказывается достаточно человеколюбивых граждан, берущих на себя воспитание таких детей, так что надобности в устройстве воспитательных домов до сих пор не представлялось. Надо прибавить, что до крайности строгие законы в Черногории по отношению к незаконному сожитию делают факты незаконного рождения крайне редкими. Каждый черногорец, виновный в рождении ребенка девушкой или вдовой, обязывается давать содержание на этого ребенка. Если соблазнитель женатый, то кроме того он приговаривается «на хлеб и воду» в течение 6 месяцев.

После устройства бывшим Бразильским Императором Дон-Педро воспитательного дома в Рио-де-Жанейро во многих городах Южной Америки возникли так называемые «детские дома»; типом их послужил Рио-де-Жанейрский дом. Питомцы этого дома, после первоначального образования в самом доме, поступают в военное училище, а затем на военную службу. Такое специальное назначение воспитательного дома, приданное ему бывшим Императором, должно быть объяснено особыми политическими условиями страны; что же касается до организации воспитания питомцев в самом доме до 14-летнего возраста, то это напоминает нам старания учредителя Московского воспитательного дома И. И. Бецкого, скоро, как мы увидим, разочаровавшегося в возможности такой организации. К сожалению, мы не имеем цифровых данных о смертности в Рио-деЖанейрском и других Южно-Американских воспитательных домах; не думаем, чтобы практикуемое в них искусственное кормление с 3-месячного возраста давало хорошие результаты, и полагаем, что все они, в конце концов, откажутся от принятой системы, как отказались от нее Европейские воспитательные дома.

Хотя в законодательстве Турции и нет недостатка в указаниях на права незаконнорожденных детей и заботы об их участи, но воспитательных домов для них, а равно и другой какой-либо формы призрения их, здесь не существует.

Таким образом, в существующих воспитательных домах мы видим однообразную систему воспитания приемышей: временное, чаще очень непродолжительное пребывание их в центральном заведении и раздачу затем на дальнейшее воспитание в частные семьи, 
по преимуществу в деревенские. У большинства из них прием детей обставлен тем или другим затруднением, что должно было явиться вследствие чрезмерной эксплуатации воспитательными домами, вызвавшей чувствительные денежные траты, а также чрезмерную смертность от скученности детей и недостатка кормилиц. Далее мы видим, что система «тура» повсеместно уступает место «явному приему». Наконец, что касается устройства деревенских округов, то отсутствие хорошей организации надзора за воспитанием детей в деревнях есть существенный недостаток всех воспитательных домов, за исключением, пожалуй, Парижского. Такой недостаток отражается в высоком проценте смертности детей в раннем возрасте (до года), восходящем в Итальянских домах до 44\%, в Австрийских до $42 \%$ и до $58 \%$ в Афинском и Бухарестском. Причин такого неблагоприятного результата следует искать в экономических условиях того класса, который берет на себя воспитание питомцев: повсюду во Франции, Италии, Австрии и пр. промыслом воспитания детей занята беднота, где материальному недостатку сопутствуют неразвитость, нечистоплотность, предрассудки и прочие неблагоприятные условия для правильного развития детского организма.

Как мы уже сказали, в протестантских государствах - Англии, Германии, Швейцарии, а также и Северной Америке воспитательных домов нет; здесь было признано открытие таких домов безнравственным. Между тем статистические данные указывают на процент незаконнорождений, превосходящий таковой в странах, имеющих у себя воспитательные дома. Что касается до существующего в этих государствах закона о праве разыскания отца (Vaterschaft), то, на первый взгляд, казалось бы, что естественнее и справедливее, как привлечение обоих родителей к воспитанию их ребенка, зачем возлагать расходы по воспитанию на дорогостоящие заведения, когда материальная сила (подобно отцу семейству) на лицо. Однако практика показала, что, во-первых, доказать отца вовсе не так легко: ограничиваться при доказательствах присягой и свидетельскими показаниями рискованно, и, во-вторых, в подобных процессах предоставляется широкий простор шантажу и корыстным целям, этим страшным врагам общественной жизни. В Германии на каждый шестой процесс приходится один такой «скандальный».

\section{III}

В России первым учреждением для сирот и незаконнорожденных детей являются «сиропитательницы», основанные в 1707 г. по личной инициативе и на собственный счет Новгородским митрополитом Иовом. О деятельности этих приютов и дальнейшей их судьбе после смерти митрополита Иова (1716 г.) исторических данных мы не нашли, за исключением лишь того, что кроме первого такого приюта в Холмовской Успенской обители их было еще в Новгороде до 10, где воспитывалось около 3000 сирот и незаконнорожденных. Эти «сиропитательницы» Иова очевидно послужили (в 1715 г.) основанием указу Петра Великого об устройстве при церквах «сиропитательных госпиталей», в которых, по заграничному примеру, практиковался тайный прием, для чего в зданиях этих приютов были сделаны особые окна, куда можно было класть приносимых детей. Содержание «госпиталей» было отнесено частично на городские доходы, частично на частные пожертвования, о вызове которых Сенатом были изданы и по всей Империи 
разосланы особые увещевания. Каждый такой церковный приют вверялся надзирательнице, на обязанность которой возлагались уход и надзор за воспитанием призреваемых детей; когда же они подрастали, то отдавались в ученье мастерству, или поступали в услужение.

Со смертью Петра Великого эти благодетельные «госпиталии» одна за другой закрылась и до 1763 г. не встречается никакого указания на существование какого-либо филантропического учреждения для сирот, незаконнорожденных или подкидышей. Между тем с эмансипацией Петром Великим женщины, случаи нахождения маленьких трупиков на огородах, в лесах и болотах стали появляться все чаще и чаще. Такое «вопиющее зло» не могло не обратить внимания Императрицы Екатерины II, всегда заботливо относившейся к общественным нуждам своего государства.

По проекту всей душой преданного делу милосердия, известного государственного деятеля того времени Ивана Ивановича Бецкого ${ }^{4} 1$ сентября 1763 г. Императрицей Екатериной II был издан манифест о построении «общим подаянием» воспитательного дома для приносимых детей, с указанием быть этому Дому учреждением государственным и «на веки под особым Монаршим покровительством и призрением». Для успешности сбора пожертвований на постройку такого дома Синодом были разосланы воззвания, которые должны были читаться в церквах всей Империи, и которые призывали кроме того устраивать самостоятельные «сиропитательницы» или приюты. В представлении Бецкого, поданном Императрице 10 июня 1763 г., читаем: «я разумею тех невинных детей, которых злощастные матери покидают, оставляют, или (что злее) и умерщвляют, которые, хотя и от законного супружества, но в крайней скудости родясь, от родителей оставлены и слепому счастью преданы бывают для того, чтобы от тяготы воспитания их освободиться и самим удобнее пропитаться можно было». В этом же представлении цель учреждения воспитательного дома определяется: «истребление злодейств; с выгодою и пользою воспитание детей; уменьшение нищенства и человеколюбия ради», для чего Бецкий предлагал учредить дома «для найденных и оставленных родителями детей, а также госпитали для родильниц». В «генеральном плане Императорского Московского Воспитательного дома», сочиненном Бецким, так формулируются правила приема детей: принимать от всякого принесшего, с одним лишь вопросом, крещен ли и какое дано имя; представлялась возможность подавать младенцев ко всем приходским священникам, богадельням, монастырям, днем и ночью, откуда они должны были пересылаться в Воспитательный дом, где за каждого принесенного младенца выдавалось два рубля за труд доставления; караулам предписывалось оказывать всякое содействие приносящим ночью.

Очевидно на создание Бецким совершенно новой для России формы благотворительности - призрения детей - повлияли прежде всего наличность подкидывания детей «столько же из-за бедности, сколько срама ради», и кроме того

\footnotetext{
${ }^{4}$ Иван Иван Бецкий, 1701 (1704 - прим. ред.) - 1795 гг., - побочный сын последнего русского боярина Ивана Юрьевича Трубецкого, бывшего 18 лет в плену у шведов. Он получил блестящее образование, много путешествовал по Европе. Обессмертил себя любовью к страждущему человечеству и просвещению России, был ближайшим и доверенным лицом Императрицы Екатерины II, имел чин действительного тайного советника, состоял президентом Академии наук, умер в С.-Петербурге в 1795 году.
} 
образцы действовавших подобных учреждений в Западной Европе, с которыми Бецкий успел ознакомиться во время своих путешествий по Европе, о чем свидетельствуют ссылки его в различных местах «плана» на Лионский и другие воспитательные дома.

Учреждением заведения с облегченным приемом детей, даже с уплатою за доставление ребенка двух рублей предполагалось, главным образом, бороться с вопиющим наличным злом - бросанием детей матерями на произвол судьбы, нередко на смерть («истребление злодейств»).

Обеспечив этими доступными правилами приема детей известную их наличность (надо думать, что Бецкий не предполагал того наплыва, который вскоре парализовал намеченную деятельность), Бецкий в своем «плане» заботливо проводит идею о воспитании из принятых в дом детей - граждан «способных служить отечеству делами рук своих в различных искусствах и ремеслах», предполагая образовать из них так называемое третье сословие (tiers état французов), сословие - среднее между привилегированным и податным, обязанное своим воспитанием государству.

Для выполнения широко задуманной задачи воспитания детей в самом доме, Бецкому понадобилась постройка такого громадного здания, каким представляется Московский Воспитательный дом, по независящим от Бецкого причинам не вполне достроенный по представленному им плану: недостает пристройки такого же квадрата, какой существует по левую сторону центрального корпуса. Пять этажей такого громадного здания должны были соответствовать пяти возрастам питомцев: 1) до 2 лет, когда дети должны были находиться у кормилиц и нянек; 2) до 6-7, когда оба пола вместе приучались к легким занятиям (воспитывать трудолюбие); 3) до 11 лет, когда дети должны были учиться в школе по 1 часу и заниматься легкими работами - вязанье, прядение, ткачество и т.п.; 4) до 14 лет, когда кроме школы, дети должны были обучаться ремеслам и домашним работам и 5) до 16 лет, когда питомцы должны работать в тут же устроенных мастерских. Образование их ограничивалось чтением, письмом, правилами арифметики и наставлением в законе Божьем.

Насколько участливо и тепло Бецкий относился к своей миссии, можно видеть из детальной разработки, правда местами наивно и повсюду платонически, сложной задачи воспитания детей. По отношению, например, к учителям и приставникам есть такие параграфы: «несмотря на то, что иные учителя из рабов (крепостные), начальник должен с ними обходиться ласково и учтиво» - для примера детям учителя должны, не упуская удобного случая, наставлять в «добродушии и честности, повиновении, трудолюбии» и пр. «Смеха достойно: обычай начинать учить с славянского языка», нужен им родной язык. В числе инструкций находим приказ о надписях на дверях и стенах в зале: «не делай другим, чего себе не желаешь», «не делай зла и не досаждай никому», или «не вреди животному и не озлобляй его» и т.п. На вопрос, нужно ли девочек учить тому, что указано для мальчиков, Бецкий дает такой ответ: «мы одолжены женскому полу рождением, уходом, пропитанием, дружбой и пр., а между тем препятствуем их просвещению». Имея в виду, что дети первое время жизни до своей юности находятся на руках у нянек, по мысли Бецкого, следует желать, чтобы такие первые учителя, первые сверстники и друзья были «смягчены в своих нравах учением». В главе о наказаниях говорится, что следует наблюдать, чтобы 
воспитатели не обходились с детьми так, как обходились с ними самими: «единый закон в доме ввести: никогда и ни за что не бить»; телесные наказания по отношению даже к нижним служителям вменяется начальникам «крайне запрещать» - чтобы не приучить юношество к суровости. В определении значения заведующего Воспитательным домом Опекунского Совета говорится: «мы должны быть отцами; не только о пище и одежде заботиться, но стараться вселять добрые сердца и благие нравы. Доходы умножать, но остерегаться, чтобы не осквернить учреждение неправедным имением. Служить только из любви, не ища награды и не страшась наказания. Изменять план с осторожностью: «известно, что лучшие публичные учреждения приходят в упадок только потому, что изобретатели частых и скоропостижных перемен больше портят узаконения, нежели поправляют, а наконец все учреждение опровергают».

Очень интересны привилегии, данные Воспитательному дому. Дом никакому месту не подчинен. Служители дома не должны быть судимы ни в каком другом месте, а если будут взяты под арест, то присылать их немедленно в дом. «Все дети и их потомство на вечное время вольные. Запрещается им вступать в супружество с крепостными, если же случится, то и другая сторона остается вольною». Муж, женившийся на питомке, остается крепостным, а жена остается вольною, кроме супружеской должности. Купец и другие чины (кроме крепостных) за ежегодный платеж 600 р. пользуются пожизненно чином и почтением «против камергера от коллегии». Они же за 25 - 1000 р. единовременного взноса пользуются «заплатой за бесчестие в равной пожертвованию сумме», за увечье же вдвое, на это дается вид и печатается в газетах. Исполнение этого подлежит немедленно чрез командиров. «От публичных позорищ - четвертая часть дохода» в пользу дома. Для увеличения доходов в пользу Воспитательного дома между прочим был учрежден сбор с игральных карт по 10 к. за игру с заграничных и по 5 к. с местного производства 5 .

Для выполнения столь широко задуманного плана постройки и содержания Московского Воспитательного дома понадобились громадные денежные средства. Своим примером щедрого пожертвования ${ }^{6}$ на это благое учреждение Екатерина II заставила участвовать и многих своих сановников и богачей того времени. Эти жертвы не всегда состояли из денежных сумм; некоторые дарили Воспитательному дому имения, дома, ценные вещи, строительные материалы и т.п. До 53 лиц предложили вносить ежегодно для Воспитательного дома известные суммы, составившие около 50000 ежегодных взносов. Не только одни ближайшие ко двору Императрицы лица принимали участие в пожертвованиях на это симпатичное дело, но действительно оно основалось согласно словам манифеста общим подаянием: в списке жертвователей ${ }^{7}$ встречается не мало купцов, мещан и крестьян,

5 Впоследствии была учреждена собственная карточная фабрика, монополия которой существует по настоящее время, доставляя существенные доходы Ведомству Императрицы Марии.

${ }^{6}$ В разное время Императрицей Екатериной II было пожаловано свыше 1 миллиона рублей.

7 Вот имена некоторых из обширного списка жертвователей: Наследник престола Павел (500 000 р.), сам учредитель Бецкий, княгиня Голицына (22 000 р.), кн. Барятинская, кн. Белосельская, князья Кантемир и Д. М. Голицын; графы Шереметев, К. Г. и А. Г. Разумовские; Миних, А. П. Шувалов, Чернышев, архиепископ Амвросий, Всеволожский, Боборыкин, крестьянин (крепостной гр. Шереметева) Сеземов (14 500 р.). 
откликнувшихся своими лептами, нередко в сопровождении очень трогательных слов похвалы благому начинанию. Были случаи присылки пожертвований из-за границы, так, напр. 100 червонцев от неизвестного из Голландии, 10000 р. от принцессы ГессенГамбургской, от Дидро и пр. В ряду жертвователей выдается известный уральский богачмиллионер Прокофий Демидов, внук кузнеца Никиты Демидова, открывшего и разработавшего богатство горы Благодать на Урале, которая была ему подарена Петром I. Богач этот отличался капризным, раздражительным и своенравным характером; с ним нередко приходилось считаться Ивану Ивановичу Бецкому, в особенности во время постройки здания Воспитательного дома, окончание которой принял на свой счет Демидов. Он не хотел подчиняться никаким указаниям экспедиции строений, третировал членов Опекунского Совета ${ }^{8}$, бесконечно (более 10 лет) тянул постройку. Несмотря на все это Бецкий крайне снисходительно относился к этому щедрому жертвователю и заступался за него не только перед членами Опекунского Совета, но и перед Императрицей. Самодурства этого богача нередко наказывались Екатериною II более или менее крупными штрафами в пользу Воспитательного дома; так, например, когда ему грозило серьезное взыскание за непристойную выходку в английском парламенте, вмешательство Императрицы повлияло на освобождение его от строгостей английского суда. Впрочем, большая часть его пожертвований была делом его личной инициативы, отличавшейся практическим, здравым смыслом. Он положил основание учреждению коммерческого училища для воспитания купеческих детей, внеся для этой цели 200 слишком тысяч рублей; на постройку родильного госпиталя им было пожертвовано 20 тысяч. По его предложению и с его денежной помощью было основано первое в России банковое учреждение - ссудная казна (ломбард), в котором ко времени освобождения крестьян оказались заложенными русскими помещиками не один миллион крестьянских душ. Ежегодный доход с этого ломбарда служил главным основанием всех средств, на которые содержались кроме двух столичных Воспитательных Домов многие другие благотворительные учреждения, возникшие вслед за Воспитательными Домами.

Через 7 месяцев после манифеста об учреждении Московского Воспитательного дома, 21 октября 1764 г., в присутствии Государыни, при громадном стечении народа, с большой торжественностью была произведена закладка здания Московского Воспитательного дома на берегу Москвы-реки, на месте, где был так называемый Гранатный двор. Кроме этого двора для строений Воспитательного дома был отдан громадный участок земли, простиравшийся по берегу р. Яузы, по улице Солянке и по протяжению стены Китай-города, от Варварских ворот до берега Москвы-реки. Этот участок кроме Гранатного двора заключал в себе обширный Васильевский сад (загородный двор Императрицы Елизаветы) и школу для солдатских детей. В память дня закладки была выбита медаль с изображением: на одной стороне - портрет Екатерины II, на другой две

Крупные пожертвования имениями были сделаны кн. Кантемиром (ценностью в 24600 р.), Кашкадамовой (535 душ крестьян), Дубинским, Собакиным, Шубским и др.

${ }^{8}$ Вместо обещанных однажды 20000 р. он прислал в заседание Совета четыре скрипки по числу членов Совета - князей Гагарина, Голицына и господ Вырубова и Умского. 
фигуры, Вера и Человеколюбие, поднимающие ребенка, с надписью вокруг «И вы живы будете. 1763 г. 1 сентября».

В день закладки во временное помещение (дом графа Чернышева) были приняты 19 младенцев, которым были даны при крещении имена Екатерины и Павла. С этого началось сложное и трудное дело воспитания брошенных детей, представлявшееся основателю этого «дома призрения» легко укладывающегося в рамки теоретически разработанного им «генерального плана».

Озабоченный на первых порах, чтобы заведение не осталось без призреваемых, Бецкий объявил премию в 2 р. за каждого принесенного ребенка. Кроме приемной Воспитательного дома были открыты отделения приема в Красном селе и на квартирах почетных опекунов. Было объявлено по всем губерниям России, чтобы оттуда присылали детей в Московский Воспитательный дом. Во многих городах по частной инициативе различных благотворителей открылись «сиропитательницы», из которых дети препровождались в Воспитательный дом целыми транспортами.

В этих отделениях Воспитательного дома дозволялось воспитывать детей лишь до 3-летнего возраста, по достижении которого они подлежали воспитанию в Московском Воспитательном доме по плану Бецкого. Если на глазах у самого Бецкого, как мы увидим ниже, дело воспитания грудных питомцев шло плохо, то не удивительно, что в этих частных сиропитательницах результат получался крайне печальный; так, например, из 417 принятых в Архангельской сиропитательнице детей до годовалого возраста умерло 377. Привозимые же дети из отдаленных провинций часто оказывались заморенными, еле живыми, так что их регистрировали отдельно от приносимых здоровых детей.

В Петербурге тоже было отделение, из которого дети пересылались в Московский Воспитательный дом. Но после того, как средства Московского Воспитательного дома достаточно возросли, в 1771 г. Императрица Екатерина II открыла и второй Воспитательный дом в северной столице. С этого времени оба столичные Воспитательные дома представляют собой совершенно однообразные учреждения, строй жизни которых руководится одними и теми же правилами и указаниями, сначала согласно плана И.И.Бецкого, а затем согласно последующим регламентациям, вытекавшим, как мы увидим, из жизненного опыта этих учреждений.

Несмотря на всю энергию Бецкого, несмотря на всю его любовь к созданному детищу, проект воспитания детей со дня приноса их до совершеннолетия в стенах Дома в скором времени потерпел фиаско.

Выбрав, согласно параграфу плана, главным надзирателем мужа богобоязненного, честного, трудолюбивого, женатого, искусного в воспитании детей, главную

\footnotetext{
9 Такие «сиропитательницы» были открыты в городах Нежине (Гулевичем), Оренбурге (губернатором Путятиным), Новгороде (губернатором Сиверсом), Белозерске (купцом Макаровым), Торопце, Нижнем Новгороде (прокурором Бахметовым), Чебоксарах (купцом Кувшинниковым), Коломне, Осташкове, Олонце, Воронеже, Казани, Архангельске, Нарве, Пензе, Тобольске, Вытегре, Ярославле, Екатеринбурге, Киеве. Все эта приюты закрылись с учреждением приказов общественного призрения.
} 
надзирательницу честную и разумную, не моложе 35 лет, эконома таких же качеств, а лекаря искусного во врачевании, в дальнейшем успехе своего дела Бецкий должен был сильно разочароваться. В первые четыре года получились самые безотрадные результаты: из принятых за это время 3147 детей умерло более 82\%, а в один из этих годов - в 1767 г. - даже 98\%, (из 1089 принесенных в живых осталось только 16 детей). Такие печальные результаты явились главным образом от недостатка кормилищ: в начале первого года их было лишь 14 и к концу года едва набралось 35, тогда как детей было принято 523, так что с первых же шагов пришлось практиковать искусственное вскармливание. С этою целью были приобретены козы, на которых возлагал большие надежды Бецкий, делавший даже собственноручные указания, как следует ими пользоваться, содержать их, ухаживать за ними и т.п. Очевидно, дело кормления козьим молоком не пошло, так как вскоре из Архангельска были выписаны 30 холмогорских коров и для них приобретена за Дорогомиловской заставой усадьба, где и основан существующий и ныне загородный дворферма. Но, как показывают статистические цифры, и при этих коровах, для ухода за которыми была составлена особая инструкция скотнику, дело не улучшилось. Несмотря на отправку в эту усадьбу, как на дачу, питомцев для вскармливания там коровьим молоком, смертность не уменьшалась, и Бецкому волей-неволей пришлось отказаться от основной своей задачи - воспитывать всех детей под строго регулируемым надзором, пришлось по примеру заграничных воспитательных домов прибегнуть к раздаче детей на воспитание в деревенские семьи. Эта отдача сначала была кратковременной, лишь до 9-месячного возраста, затем она удлинилась до 5-ти и потом до 7-летнего возраста, вследствие усиливавшегося наплыва приносимых детей, причинявшего чрезмерную скученность. По достижении этого возраста для дальнейшего, согласно плану, воспитания дети возвращались обратно в Воспитательный дом.

Эта новая система, вызванная предупреждением чрезмерной смертности детей в стенах Дома от недостатка кормилиц и скученности в еще недостроенных зданиях, повлекла за собой, во-первых, новый расход на уплату деревенским воспитателям по два рубля в месяц за ребенка, во-вторых - устройство надзора за воспитывающимися в деревнях детьми, для чего были назначены объезжие надзиратели (врачи), и, наконец, в третьих - этой системой изменялся самый существенный параграф генерального плана: образовывать из питомцев городское сословие. Вначале, когда еще не чувствовалось переполнения Дома питомцами, возврату из деревень подлежали все без исключения розданные туда питомцы, но впоследствии (с 1797 г.) был установлен комплект в 500 чел., подлежащих воспитанию в Доме, остальные же оставались на воспитании в благонадежных крестьянских семьях и по достижении 17 лет мальчики перечислялись в казенные крестьяне, им отводился участок земли и их снабжали семенами из сельских запасных магазинов; девочкам же, если они не выходили замуж, выдавались увольнительные свидетельства.

\section{IV}

Познакомимся теперь с обстановкой жизни питомцев и формой их воспитания, практиковавшегося в стенах Воспитательного дома под руководством самого Ивана 
Ивановича Бецкого.

Принятый в Воспитательный дом ребенок записывался под очередным номером в книгу, где отмечались: день и час приема, его имя, а также описывалось все объявленное о принесенном ребенке, одежда, в которой он доставлен, знаки на теле, родимые пятна и пр. Если ребенок был не крещен, то крестился, и при этом, чтобы избежать духовного свойства, для мальчиков был один священник, для девочек другой. На шею ребенка надевался крестик с тем очередным номером, под которым он был записан в приемную книгу. Ребенок поручался кормилице, если находилась свободная (дозволялось одной кормить двух детей), или няньке для рожкового вскармливания, по особым издаваемым инструкциям, часто изменявшимся в зависимости от неуспехов того или другого способа приспособления коровьего и козьего молока. У кормилиц и нянек дети оставались до 2 лет, с этого времени - «когда сами ходить начинают» - до 6-7 лет оба пола воспитывались вместе в «больших покоях»; им, по рекомендации натуралиста Саншеса, давалось сколько и когда хотят ржаного хлеба («не сырого, как у солдат»), на обед и ужин полагались щи, мясо, рыба и каша («как у мещан, порядочно живущих»), по праздникам «пирожное». В виду того, что «у детей жару больше», одежда их делалась легкая, а для привычки и укрепления тела дети должны были ходить в комнатах босиком, для выхода наружу имелись и чулки, и каты. Надзор за ними поручался избранным надзирательницам, которым вменялось следить, чтобы детские игры происходили «без стеснения, ибо по приказанию веселиться невозможно». Что касается до обучения детей с 5-летнего возраста до «пока сами одеваться могут», то в числе указаний встречается интересный параграф, запрещающий раннее обучение молитвам, знакомство со сказками и дьявольским наваждением, ибо все сие «приводит смысл детей в замешательство, помрачает ложными понятиями». Рекомендуется внушать познание о Боге, любовь к животным и т.п.; с целью приучать зрение рекомендуется обучать немножко рисованию и чтению. В виду трудности нахождения толковых, хороших воспитателей указывается «ограничиваться хотя бы и такими, которые не учили бы худым делам и не портили здоровье детей».

С 7 лет мальчики воспитывались отдельно от девочек, в этом возрасте до 11 лет дети посещали ежедневно по 1 часу школу, где обучались молитвам («Отче Наш», «Верую» и две молитвы специальные для питомцев), читать («не громко, как в школах»), писать и начальной арифметике. В остальное время дети занимались работами и рукоделием: вязаньем чулок, колпаков, сетей, работами в саду, для девочек - пряжа тканья, плетение кружев и т.п. В более старшем возрасте от 11-14 лет образование расширялось преподаванием искусства вести счет купеческий, «называемый бухгалтерией по Итальянскому обряду», а равно и «нужной для всякого купца географии». В этом же возрасте увеличивается и круг работ: чесание шерсти, тканье шелковых лент, полотна, шитье белья, а равно и домашние работы - стряпня кушаний и печенье хлеба.

После 14 лет питомцев отдавали в обучение ремеслам, для чего были приглашены мастера «трезвого поведения», за ними следили, чтобы хорошо обращались с питомцами. По окончании ученья питомцы могли оставаться в мастерских на правах мастеров, причем отдавалось преимущество тем из них, кто женится на питомке; такой новобрачной паре выдавалось полное обзаведение для их семейной жизни. Способные из питомцев отправлялись в Императорскую Академию Художеств, в Петербург. 
В своем докладе Императрице Бецкий говорил: «Вы хотите, чтобы с изящным разумом изящнейшее соединилось сердце: ведь качество разума не занимает первой степени в достоинствах человеческих, украшая, а не составляя их... Вселенная свидетельствует: Петр Великий создал в России людей, Ваше же Величество вкладывает в них души». Чтобы выполнить такую задачу при воспитании питомцев, Бецким было издано руководство учителям, приставникам и надзирательницам. Насколько он был искренно уверен в возможности такими регламентациями достигнуть желаемого, свидетельствуют те подробности, граничащие с наивностью, которыми переполнены все подобные инструкции, разбитые на параграфы. В третьей части «плана», в главе, трактующей, как следует поступать с учителями и приставниками, говорится, например, что с ними начальники должны обходиться ласково, приятно и учтиво для примера детям. Выговор им можно делать отнюдь не в присутствии детей. Учителя должны не упускать удобного случая наставлять детей в добродушии, трудолюбии и т.п. Рекомендуется веселость, «без уныния и печали». Чтобы развить в детях милосердие и добрые побуждения, на дверях и на видных местах в залах были надписи в роде: «не делай другим чего себе не желаешь», «поступай с другими - как хочешь, чтобы с тобой поступали», «не вреди никакому животному и не озлобляй его», «не лги», «не будь никогда праздным».

Глава о наказаниях в «плане» Бецкого свидетельствует, насколько действительно был гуманным этот бесконечно добрый человек. «Нет, говорит она, в Европе законов, способствующих предупреждению зла. Следует внимательно наблюдать, чтобы воспитатели не обходились с детьми так, как с ними обходились. Единый закон надлежит в доме ввести: никогда и ни за что не бить». Дозволительные формы детского наказания: 1) стоять на одном месте, 2) не пускать гулять, 3) выговор наедине, 4) выговор публично, 5) без обеда и завтрака, но никогда без ужина (это в виде поста - в течение дня хлеб и вода).

Будучи недоволен иностранными книгами для питомцев (в переводах), так как они предназначаются не в философы и не на духовные должности, а в художники и ремесленники, Бецкий проектировал издания «кратких нравоучительных книг», в которых излагалось бы: «познание о Боге, добродетели, почтении к отцам и матерям, благодетелям и наставникам, преданности Царице и т.п.». Форма изложения рекомендуется вопросная с ответами, например: «Какие есть средства благодеяния?»- Ответ: «Гостеприимством, терпением»; «Что есть гостеприимство, терпение и т.п.»?

Не менее платонически звучат и другие параграфы «генерального плана», относящиеся к управлению Воспитательным Домом. Управление поручалось Опекунскому Совету, состоящему из лиц выдающегося положения в обществе и пользующихся особым доверием Императрицы. Так как Воспитательный дом состоит под Высочайшим покровительством, читаем во II части «плана», и независим ни от каких правительств, то «правление над ним должно заслуживать благоволение и похвалу от общества». Законы для членов Совета «одни лишь естественные, надо, чтобы совесть была строгим над ними судьей». Доходы рекомендуется умножать, но остерегаться, чтобы «не осквернить учреждение неправедным имением, следует иметь омерзение к доходам, стесняющим общество и утесняющим бедных». Служить предлагается «только из любви, а не из награды и не страшась наказания». Не изменять «генерального плана», а если понадобится, то не иначе как с согласия всего Совета. 
Первыми почетными опекунами были, кроме Бецкого, князь С. Гагарин, П. Вырубов, И. Тюняев, Б. Умской и А. Дурново.

Непосредственное управление Домом вверялось Главному Надзирателю, на правах полного хозяина во внутренней, административной жизни учреждения, под руководством Почетного Опекуна, заведующего экспедицией (Опекунского Совета) о питомцах. Первым таким надзирателем был Иван Юрьевич Рост (профессор). В помощь Главному Надзирателю (отцу несчастно-рожденных сирот) назначалась Главная Надзирательница, заменяющая детям место матери. Она по «плану» должна иметь добродетели «приличные своему полу, не подвергая себя слабостям оного». Ближайшими сотрудниками Надзирателя были его помощники - главный доктор, эконом, экспедитор и архитектор.

Итак, поступивший под опеку Воспитательного дома ребенок должен был пользоваться всеми благами отеческого призрения, заботившегося сначала о его теле, а затем и о воспитании из него полезного для отечества гражданина. Опека эта продолжалась до совершеннолетия питомца, по достижении которого питомец, обучившийся (непременно) какому-либо мастерству, представлял из себя «третий чин»- свободного ремесленника. Ввиду того, что такие ремесленники хотя и могли находить для себя занятия у купцов, торговцев и фабрикантов, но у таковых, в особенности у раскольников, питомцы могли встретить «ненависть и пренебрежение», то проектировалось устройство собственных фабрик, куда они и могли бы поступать мастерами.

Мы уже отметили, что жизненный опыт вскоре же показал невозможность применения намеченных в плане условий призрения. Всех детей воспитывать в самом доме становилось немыслимым и некоторым из питомцев по достижении совершеннолетия пришлось всё-таки вместо третьего сословия заняться обработкой земли, на правах казенных крестьян.

Что касается отдачи детей на временное воспитание в деревни, то она нисколько не повлияла на уменьшение процента их смертности в грудном возрасте. Хотя с введением этой системы в самом Воспитательном доме встречается понижение процента смертности с 98,5 до 45,5 и даже до 24,6\%, но зато из 30014 отправленных за 32-летний период в деревни умерло там 22556 (75\%) и только 4966 или 13\% были возвращены для дальнейшего воспитания в Воспитательный дом, из остальных 2492 питомцев часть осталась в деревенских семьях, а некоторые пропали без вести или вернее были тайно закрепощены помещиками тех селений, где находились на воспитании.

\section{$\mathbf{V}$}

После смерти И. И. Бецкого, последовавшей в 1795 г., Императрица Мария Федоровна приняла в свое ведение оба Воспитательные дома и время ее управления этими учреждениями полно неустанных забот и теплого отношения к участи призреваемых. Кроме общего руководства Воспитательными домами и другими возникшими под ее покровительством заведениями, Императрица находила время для личного знакомства с жизнью детей в заведениях, для личного участия в судьбе отдельных лиц из числа призреваемых, для личного указания приемов обхождения с детьми. Пребывая по 
нескольку часов кряду в стенах заведений, императрица находила случаи знакомиться с характером, способностями детей, и пользовалась этим для своих указаний и направления трудного дела воспитания брошенных родителями детей.

Участие Императрицы Марии Федоровны в управлении Воспитательными домами прежде всего выразилось резким изменением учебной части заведения. По ее указанию практиковавшееся одностороннее распределение занятий питомцев по возрастам было заменено разделением по индивидуальным способностям: оказавшиеся способными к письму посылались на службу по письменной части, способные к арифметике - по счетной части, другие направлялись в аптеку и т.п. С 1807 г. были открыты так называвшиеся «латинские классы» для питомцев, назначенных к поступлению в медикохирургическую академию. Эти классы впоследствии были преобразованы в две параллельные гимназии с десятилетним курсом. Из гимназий питомцы, не имевшие наклонности к медицине, поступали в Университет. Многие из окончивших курс в латинских классах впоследствии занимали выдающиеся должности по администрации, немало вышло из них достойных и ученых докторов и даже профессоров Университета ${ }^{10}$. Не оканчивавшие курса в «латинских классах»- менее способные поступали в фельдшера при Военном Госпитале, в фармацевты в имении графа Разумовского - Горенки, в садовники - в Симферопольский Никитский сад, в земледельческую школу и в ремесленное заведение (ныне Техническое училище).

Девочек-питомок, обучавшихся до этого одному лишь рукоделию, стали посылать в открытый при родильном госпитале Повивальный Институт (с 1800 г.), где они обучались повивальному искусству и по окончании курса рассылались по разным городам России. С целью удовлетворить потребность общества того времени, при Воспитательном доме были учреждены для питомок «Французские классы», в которых приготовлялись учительницы и воспитательницы (гувернантки). Была даже попытка из питомок и питомцев образовывать учителей музыки, для чего из-за границы был приглашен Гарткнох, ученик Гуммеля, и хотя эти музыкальные классы и выпустили недурно приготовленных учителей и учительниц, но классы эти пришлось всё-таки закрыть, так как на таких учителей не было спроса, и они оставалась без места. Впоследствии музыкальные классы слились с общим преподаванием.

Полный курс учения гувернанток, начиная с приготовительного класса, равнялся одиннадцати годам, так что воспитанницы поступали на должность наставниц на двадцатом году своей жизни. Отношения их к семействам, в которые они поступали из Дома, были ясно регулированы в печатных кондициях; жалованье определялось, смотря по разряду, в который зачислялась окончившая курс «кандидатка» по успехам, определявшимся на экзамене.

Между тем принос детей в Воспитательный дом с каждым годом все возрастал: в 1795 г. он равнялся 1921 ребенку, в 1805 г. 2 660, в 1815 г. уже 3 082, в виду этого не было уже и речи об уплате двух рублей, выдававшихся Бецким в первые годы существования

\footnotetext{
${ }^{10}$ По успешном окончании курса в Академии или Университете некоторые воспитанники отправлялись для усовершенствования в науках за границу на специально для этой цели пожертвованные княгиней Голицыной средства.
} 
Дома, напротив приходилось придумывать различные меры к ограничению приноса младенцев. К числу этих мер относится учреждение в 1807 г. городского воспитания, т.е. предоставлялось матерям за известную плату воспитывать своих детей на дому, причем плата эта продолжалась до 7-летнего возраста. Кроме того, матерям, продержавшим своих детей до 4-х недельного возраста и затем представившим их в Воспитательный Дом крещенными со свидетельством священника, выдавалось денежное вознаграждение за первую неделю - 4 р., за вторую - 3 р., за третью - 2 р. и за четвертую - 1 р. 50 к. Этою мерою предполагалось уменьшить отдачу детей в Воспитательный дом, развив за этот период материнскую привязанность к ребенку; рассчитывали вместе с тем получать после этого срока ребенка с укрепившимися на молоке матери силами и более здоровым и выносливым, чем при приносе его тотчас по рождении. Другая мера к ограничению приноса состояла в уменьшении шансов попасть ребенку в комплект получающих воспитание и образование в самом Воспитательном доме. С 1798 г. были учреждены особого рода пансионеры из тех детей, при приносе которых были прилагаемы 100 р., такие дети не отсылались в деревню, а воспитывались в Доме. Можно было вносить эти 100 р. и после того, как ребенок уже был отправлен в деревню - когда он достигал возраста 6-10 лет; в таком случае он возвращался из деревни в Дом и мог пользоваться всеми благами пансионера. Понятно, как легко можно было злоупотреблять таким правом: родители выжидали, останется ли их ребенок в живых, и таким образом не рисковали своими ста рублями. Явилось крайнее затруднение в размещении всех таких неожиданных пансионеров; тогда Опекунский Совет постановил зачислять в пансионеры одних лишь новорожденных детей, перевод же из деревень в пансионеры запретить. Несмотря, однако, на такие паллиативные меры, принос не убавлялся, недостаток в кормилицах не мог быть устранен никакими издержками, награждениями и поощрениями, и вот в 1811 г. в Петербургском Воспитательном доме вводится опыт уничтожения тайного приема детей; тоже проектировалось ввести и в Московском Воспитательном доме, но события 1812 г. помешали исполнению этого проекта, а в 1815 г. эта мера была отменена и для Петербургского Воспитательного Дома.

Так как Воспитательный дом принимал подкидышей не только новорожденных, но и старшего возраста, то бывали случаи подкидывания 5-летних и старше, даже со свидетельствами о законности рождения: так заманчиво было даваемое им воспитание. В виду этого в 1830 г. последовал суровый указ - взамен оставления подобных подкидышей в Воспитательном Доме, зачислять их в кантонисты и даже никогда их не возвращать родителям, если они будут просить об отдаче их. Девочек же воспитывать непременно в деревнях, отнюдь не причислять их к учебным классам, а если брать в Воспитательный дом, то лишь на должности прачек и служанок.

Ввиду того, что число питомцев, получающих воспитание в стенах Воспитательного дома, было ограничено 500-ми человек, в число которых входили частично оставшиеся (пансионеры) со дня приема в дом, большею же частью возвращенные из деревень после 7летнего возраста, остальных питомцев приходилось оставлять на воспитание в крестьянских семьях. С увеличением общего числа питомцев увеличивался сам собой и комплект таких деревенских питомцев. Обязанность приискивать надежных воспитателей была возложена (в 1797 г.) на экспедицию Государственного Хозяйства. Надзор за 
воспитанием питомцев в деревнях был поручен особым членам Опекунского Совета, из числа которых особо деятельным явился для Московского Дома А. В. Салтыков. По его предложению существовавшие объезжие надзиратели заменены объезжими лекарями, селения же, в которых воспитывались питомцы, разделены сначала на десять, а затем на 12 округов, соответственно числу лекарей. Округа эти составляли селения, находившиеся сначала лишь в пределах Московской губернии, и только впоследствии были расширены на счет соседних с нею уездов других губерний. На обязанности объезжих лекарей лежали осмотр детей на месте воспитания не менее двух раз в месяц, подача в случае заболевания медицинской помощи, раздача причитающихся за воспитание денег, поверка наличности питомцев, приглашение кормилиц в Воспитательный дом и пр., и пр. К числу недостатков этой первоначальной организации надзора за деревенским воспитанием следует отнести неудобное распределение округов по сторонам дорог, около которых были расположены отнесенные к округу селения, а главное, что надзиратели жили в Москве и отсюда по временам только ездили на осмотр питомцев.

Впоследствии (с 1857 г.) окружные надзиратели, заменившие собой объезжих лекарей, обязаны были проживать в самых округах, район которых определялся чаще всего границами уезда. Деятельность окружных надзирателей проверялась периодическими ревизиями объезжих надзирателей. Заменяя лекарей чиновниками, начальство Воспитательного дома имело в виду сбережение средств, так как лекарям приходилось платить большее жалованье, но, как показал опыт, чиновники с жалованьем в 200 р. в год далеко не оправдали доверия, объезды их были крайне редки, наличность питомцев не соответствовала действительности, многие воспитатели, подчас не без ведома надзирателя, по многу месяцев после смерти питомца продолжали получать деньги за воспитание такого покойника, нравственные качества таких дешевых надзирателей часто не соответствовали назначению, эксплуатирование труда взрослых питомцев и их воспитателей граничило с произволом любого помещика. Как мы увидим ниже, надзор за деревенским воспитанием вступил на должный путь лишь после реорганизации этого дела в 1870 году.

Таким образом, с развитием деятельности Воспитательных домов гигантскими шагами возрастали затруднения в исполнении задачи, положенной в основание этого благотворительного учреждения. Детей приносят все более и более, для их размещения кормилиц недостает, недостает места, обращаются к помощи деревенских воспитательниц, их тоже не хватает, приходится увеличивать расход на их привлечение. Но вот дети так или иначе розданы по деревням. Однако, не говоря уже о их смертности в зависимости от условий бесконтрольного вскармливания и ухода в грязной, крестьянской хате, необходим за ними надзор, надзор этот поручается мелким чиновникам, число их по разбросанности мест воспитания недостаточно, нравственные их качества неудовлетворительны, в результате затрата труда и средств, не соответствующая результату благотворительной цели учреждения: из громадного числа принимаемых в заведение детей незначительное только меньшинство их пользуется намеченными учреждением благами. В то время как это меньшинство в палатах Воспитательного дома, на глазах у бдительного начальства питается кормиличным молоком, или рожком на загородном дворе, готовится в доктора, чиновники, обучается в «латинских» и «французских» классах, танцует и поет, большинство тех же несчастнорожденных умирает в курной избе деревенских 
воспитательниц, бесконтрольно питающих их чем Бог послал, помогает в немудром хозяйстве своих мамок, учится обрабатывать землю, к которой в конце концов и приписывается. Эта закулисная сторона не поражала своей действительностью, так как попадалась на глаза лишь в форме мертвых чисел отчетности, тогда как казовая сторона была на лицо, во всей увлекательной ее форме.

\section{VI}

После смерти Императрицы Марии Федоровны (1828 г.), взгляд правительства на образование «третьего сословия» резко изменяется в тридцатых годах. В таких безродных, ничем необеспеченных гражданах признается ненужный государству пролетариат и в 1837 г. все существовавшие «классы» - ремесленные, акушерские, ученые, музыкальные и т.п. предписано уничтожить, обратив их в образовательные заведения для обер-офицерских сирот, питомцев же впредь из деревень обратно не возвращать, оставляя их навсегда в крестьянских семьях, в которых они должны приучаться к хлебопашеству и в будущем составлять из себя исключительно сельское сословие, приписанное к казенным селениям. Кроме того, практиковалось поселение питомцев в особых колониях, основание которых относится к 1826 г., когда была устроена в Саратовской губернии первая (Мариинская) колония; для той же цели было еще имение в Смоленской губернии. Достигнувших совершеннолетия питомцев венчали на питомках (по жеребью) и, снабдив их хозяйством лошадью, коровой, сельскохозяйственными инструментами, семенами и т.п., отправляли в колонию, где им отводился участок земли и давалась изба. Такая колонизация практиковалась недолго, лет 7-10; это стоило больших денег, производилось заочно, и в практическом отношении мало надежно: какие самостоятельные хлебопашцы могли из них выработаться в возрасте 21 года, при н насильном отторжении их от семей, хотя и не родных по крови, но с которыми сроднили их годы воспитания. Впоследствии эти колонисты и потомки их, считая себя на особых правах «казенных детей», причиняли немало хлопот правительству по усмирению, так как они протестовали против обложения их земскими и другими повинностями.

После сказанного преобразования в условиях быта питомцев, обширные помещения Воспитательного Дома, занятые различными «классами», были отданы под Николаевский институт для штаб и обер-офицерских сирот, которых оказалось особенно много после холерных эпидемий 1837-38 годов. Институт этот и в настоящее время помещается в здании Московского Воспитательного дома, отвоевав себе большую часть главного здания, в котором почти только один пятый этаж остался в распоряжении собственно Воспитательного дома, превратившегося с 1837 г. только во временную станцию для грудных детей, которые отсюда раздаются на воспитание в крестьянские семьи, где и остаются до совершеннолетия, по достижении которого приписываются в мещанское сословие. Ниже нами будет разобрано значение этой реформы для судьбы питомцев, с 1837 г. изменившейся в корне против намеченной основателем Воспитательного Дома.

Принцип воспитания всех питомцев непременно в деревне, проведенный в указе 1837 г., остается до сих пор неизменным; лишь правила приема, раздачи детей в деревни, их быт, надзор за ними и т.п. много раз изменялись за это время: изменения находились в 
зависимости частью от взглядов руководителей дела, частью в зависимости от различных факторов, имевших общегосударственное значение. К числу таких факторов относятся освобождение крестьян, быстрое развитие железнодорожных путей, подъем отечественной промышленности, общая воинская повинность и проч.

При крепостном праве помещику был прямой расчет в увеличении числа его крепостных душ, в этом расчете ему было все равно, законная или незаконная душа увеличивала его благосостояние. Незаконнорожденные дети крепостных девок редко попадали в воспитательные дома; мало того, обнаруживались случаи пропажи питомцев, самовольное присвоение помещиком ребенка, попавшего на воспитание в крепостную семью. Усыновление питомцев крепостными крестьянами было невозможно, так как питомцев ни под каким видом не было дозволено закрепощать. Таким образом, крепостное право в одно и то же время и убавляло контингент лиц, могущих усыновлять питомцев, и ограничивало район воспитания их селениями казенных крестьян. Кроме того, всегда нуждающиеся в кормилицах воспитательные дома должны были мириться с запретом помещиков, не пускавших своих крестьянок в кормилицы в воспитательный дом. Нетрудно себе представить последствия освобождения крестьян. Всякая кормилица вольна идти в кормилицы в воспитательный дом, вольна взять себе на воспитание питомца, усыновить его, женить, выдать замуж, так или иначе водворить в свою семью, разделив с ним и надел свой. Вместе с тем давалось новое право - свободная отдача в воспитательный дом остававшихся до того в деревне незаконных, а, как увидим ниже, подчас и законных детей. Таким образом, увеличился район благотворительности с одновременным увеличением недостающих кормилиц и мест для деревенского воспитания питомцев.

Один за другим вырастают в Москве вокзалы железных дорог, соединяющих этот центр с отдаленными центрами России. В этих уголках до того и в ум не приходило о легкости помещения в Московский воспитательный дом «незаконного», а то и «лишнего» ребенка; к тому же, вследствие изданного Императором Николаем I закона, воспрещавшего открывать в России новые воспитательные дома, такого ребенка некуда было и девать, и вот в тайную приемную Московского дома из различных мест повезли детей особые, вновь народившиеся специалистки-доставщицы, повезли не в одиночку, повезли гуртом, целыми корзинами. Чтобы не делать лишнего проезда, доставщица детей, получив свой гонорар за доставление ребенка, дожидалась других попутчиков и, когда пятый или седьмой поступали ей на руки, то времени протекало достаточно, чтобы первый ей доставшийся успел у нее наголодаться до того, что она доставляла его в Воспитательный дом еле живого: бывали случаи и смерти таких детей в дороге. Такая гуртовая доставка, практиковавшаяся до последнего времени, теперь преследуется начальством, да и новые правила приема, как увидим далее, должны были ее парализовать. А так как по действовавшим правилам отказа в приеме никому не могло быть, то в Московский Воспитательный дом доставлялись дети как из Москвы, так и из уездов, из соседних губерний, доставлялись и из Вологды, из Астрахани, даже из Берлина и Версаля; немудрено, что с 500 принесенных в первый год основания Московского дома дело дошло до 17 слишком тысяч детей, принятых им в 1889 году.

Выросшие в громадном числе как в Москве, так и в ее окрестностях фабрики и заводы повлекли к себе, работников и работниц, бросивших для того свою деревню, а с ней 
и деревенские нравы, променяв их на специфические фабричные. Молодость, фабричная свобода, с ее разгулом, близкое общение молодух с парнями несомненно увеличили контингент «пригульных» детей, а с тем вместе и работу в приемной воспитательного дома. В то же время фабрики повлияли как на число кормилиц для воспитательного дома, так и на число деревенских воспитательниц питомцев, убавив то и другое. Фабричный заработок, с одной стороны, и свобода жизни, с другой, привлекательнее для той, которая при других условиях охотно шла в кормилицы и брала себе на воспитание ребенка.

Общая воинская повинность, с своей стороны, тоже не могла не повлиять на строй жизни воспитательных домов. Откладывая свою свадьбу до отбытия солдатчины, молодые деревенские и городские люди удлиняют свой холостой век, с его неответственностью перед законом и любовницей за прижитого незаконного ребенка, место которому уготовано опять-таки в приемной воспитательного дома.

Привлечение городами деревенского люда, ищущего здесь заработка и пропитания, не получаемого от кормилицы-земли, не соответствующей по своему наделу числу семейных ртов, поселило в нем небывалый до того обычай расставаться с родным законным ребенком: он сделался, вопреки всему складу христианской души народа, лишним, освободиться от воспитания его явилось потребностью в зависимости от материальной нужды, тайная приемная воспитательных домов без отказа брала на себя заботу о воспитании и такого законного ребенка, участвуя этим вместе с родителями в преступлении - сокрытии законных прав ребенка.

Каждый из этих факторов в отдельности и все вместе прежде всего повлияли на увеличение числа приносимых детей. С этим увеличением возросло затруднение, с одной стороны во вскармливании их в Домах, с другой в приискании для них деревенских воспитательниц. В результате - громадная смертность до годового возраста как в стенах воспитательных домов, так и в деревенских кругах, а с этим вместе и нарекание на учреждение, имеющие девизом своим «и вы живы будете!».

\section{VII}

В Московский Воспитательный Дом было принято детей:

$\begin{array}{lc}\text { в } 1764 \text { г. } & 523 \\ \text { в } 1783 \text { г. } & 1155 \\ \text { в } 1803 \text { г. } & 2598 \\ \text { в } 1823 \text { г. } & 4655 \\ \text { в } 1843 \text { г. } & 7274 \\ \text { в } 1863 \text { г. } & 11664 \\ \text { в } 1883 \text { г. } & 14514 \\ \text { в } 1888 \text { г. } & 17114\end{array}$

Из этой таблицы видно, как возрастало в каждое двадцатилетие число призреваемых детей - пока оно не дошло до той цифры, которая побудила признать необходимым реорганизовать прием детей в воспитательные дома.

Так как с 1837 г. помещения воспитательных домов превратились лишь во временную станцию для принимаемых грудных детей, то первой и единственной заботой в 
самом Доме было обеспечение принятому ребенку грудного кормления, т.е. приискание кормилиц для всего наличного числа детей. Но равновесие между числом детей и кормилиц прогрессивно нарушалось, в особенности в летние месяцы (рабочую пору), когда недостаток кормилиц доходил до громадной цифры: приходилось одной кормилице поручать двух детей, или даже двум кормилицам пять детей. Понятно, что при таком условии кормиличное питание каждого ребенка не могло быть обеспеченным; как бы хороша кормилица ни была, а таковых, к слову сказать, бывало крайне мало, но досыта накормить двух детей, неся вместе с тем и днем и ночью обязанности по уходу за ними, она конечно не могла. Дабы предупредить возможное голодание детей при таком недостатке кормилиц, приходилось практиковать искусственное прикармливание различными модными суррогатами женского молока ${ }^{11}$.

Опыты искусственного вскармливания детей в воспитательных домах никогда не удавались, они всегда давали безотрадные результаты. Возраст большинства детей, принимаемых воспитательными домами, от 1 дня до 3 недель, т.е. такой, когда искусственное кормление менее всего пригодно, когда желудок такого младенца не в состоянии справиться с пищей, более грубой, чем женское молоко. Неуспех искусственного кормления, кроме того, лежит еще в условиях массового вскармливания: тогда как вскармливающийся искусственно ребенок в семействе обеспечен в строгом надзоре приготовлением, приспособлением коровьего молока, количеством его, температурой и пр., при массовом кормлении неизбежно проскальзывают те детальные условия, в которых и заключается возможный успех такого кормления. Неуспех искусственного вскармливания выражался в почти поголовном заболевании вскармливавшихся детей расстройством желудка, если и не приводившим непосредственно к смерти, то вызывавшим собой истощение, от которого впоследствии дети и погибали, несмотря на прекращение опыта, т.е. перевода на грудное молоко. Искусственное прикармливание, т.е. добавочное к недостаточному грудному кормление тем или другим суррогатом, переносится детьми в особенности более старшего возраста, с менее гибельными последствиями, притом оно может быть всегда ограничено, или временно прекращено.

Итак, детей чересчур много, кормилиц недостает, искусственное кормление идет неудачно, при этом еще скученность детей - в результате $44,8 \%$ смертности $^{12}$ в стенах Воспитательного Дома и справедливое нарекание на учреждение с девизом «и вы живы будете».

Но дело не ограничивается одним этим нареканием. Так как исторический опыт воспитательных домов всего света давно заставил их отказаться от воспитания детей в своих центральных зданиях, с тем чтобы передавать их на дальнейшее воспитание в крестьянские семьи, то эта часть деятельности воспитательных домов, затрагивающая

${ }^{11}$ Из числа суррогатов нами были испробованы: разбавляемое водой коровье молоко с прибавлением аравийской камеди, соды, Паульковской соли, лактина, разбавление отварами овса и ячменя, Швейцарское сгущенное молоко, Швейцарская овсяная мука, сгущенное кобылье молоко, Гефтнеровское детское молоко.

${ }^{12}$ В 1889 году. 
собою многие общественные интересы, в свою очередь вызвала более или менее справедливые упреки.

Для ясности представления условий деревенского воспитания, его следует строго разделять на воспитание грудного питомца и воспитание в последующих возрастах. Что нужно, чтобы обеспечить надежное воспитание грудного ребенка в деревенской семье?.. Сердечное, любовное отношение кормилицы, заменившей ребенку мать, разумное грудное кормление, таковое же гигиеническое содержание ребенка. На деле вместо сердечного отношения - материальные выгоды, воспитание за плату или, лучше сказать, из-за платы, вместо разумного и гигиенического ухода - невежество, грязь и предрассудки. При таких условиях взамен надежного воспитания воспитательным домам приходится предъявлять требование лишь к возможному, сносному воспитанию, обеспечивая его так или иначе организованным надзором.

Будучи переполнен детьми и не имея возможности содержать для них стационарных (так называемых полугодовых) кормилиц, Воспитательный дом старался привлекать из деревень кормилиц, могущих исполнять эту обязанность по их домашним условиям только у себя в семье. Потребность в достаточном числе таких кормилиц вынуждала Воспитательный дом относиться снисходительно к предлагающим свои услуги; он не имел возможности при этих условиях делать выбор не только по нравственным качествам и материальному состоянию, но, к сожалению, и по качеству грудного молока. Действовавшие правила приема детей заставляли большинство матерей отдавать своих детей в возможно раннем возрасте - до отпадения пуповин (таких детей поступало 76\%), так что при наличности переполнения детьми, недостатке постоянных кормилиц и стремлении побольше передать детей деревенским кормилицам, к этим последним дети поступали в возрасте трех, двух даже недель, в возрасте слишком нежном, чтобы бороться с тою обстановкой, куда они попадали. Нет надобности распространяться об этой обстановке: кто не знает, кто не видал хаты, переполненной спящими вповалку крестьянскими душами всех возрастов, кто не видал традиционной люльки или «зыбки», привязанной к ноге бабушки, кто не возмущался видом заскорузлой соски, торчащей изо рта несчастного малютки. Неудивительно, если при этих условиях к солидному проценту смертности грудных детей в самом Воспитательном доме приходится прибавлять еще более внушительный - 48,5-66,4\% (только до годового возраста) в деревнях.

Воспитательный дом в своих заботах об обеспечении питания призреваемых им малюток изыскивал средства к привлечению кормилиц (в форме денежных премий, наград и т.п.), и если он и достигал своей цели, привлекая до 14000 кормилиц в год, то этим самым он отнимал матерей-кормилиц у их родных детей, которых они, лишая грудного молока и не всегда обеспечивая коровьим, тем самым обрекали на истощение и преждевременную смерть; это обстоятельство служило также мишенью для упрека воспитательным домам.

Отдача деревенским кормилицам детей в столь раннем возрасте, как 1-3 недели, лишала возможности проследить у таких детей проявление признаков врожденного сифилиса, как известно, затягивающееся нередко до 6 недель и более. Случаи проявления этой болезни у грудных питомцев после прибытия их в деревню и последующие заражения 
кормилиц и семейств их в свою очередь давали условия для нарекания на Воспитательный дом, как на рассадник этой болезни среди сельского населения.

Существовавшая система тайного приема детей давала возможность помещать в воспитательные дома наравне с ребенком, не имеющим ответственного за свое воспитание отца - незаконным, и того законного ребенка, чьи родители из бедности, скупости, подчас из каприза желали отделаться от своих естественных обязанностей к нему и, наконец, такого законного ребенка, рождение которого пожелали скрыть из каких-либо корыстных целей родственники или посторонние люди. Словом, служа средством сохранять тайну родов у незамужних матерей или вдов, тайный прием давал возможность безнаказанно производить преступления, караемые общими государственными законами, каковы: прелюбодеяние, неисполнение родительских обязанностей, сокрытие прав состояния, подмена детей и т.п.

Вот условия, в которых вращалось до самого последнего времени дело призрения детей в наших воспитательных домах. Учреждение, более столетия несущее на себе сложную задачу замены собою отца и матери несчастнорожденным детям, учреждение, по идее своей полное милосердия, полное лучших намерений в своем участии к судьбе брошенных детей, в истории своей полное фактов, указывающих на постоянное стремление к улучшению общего своего строя, насчитывающее в ряду своих деятелей немало лиц, всей душей преданных делу призрения - взамен благодарности к нему, испытывает сыплющиеся на него со всех сторон одни лишь упреки.

Причину этого надо искать в непосильной задаче, взятой на себя двумя нашими воспитательными домами. Тайным приемом детей учредителями были раскрыты настежь двери воспитательного дома для всех желающих им воспользоваться, без ограничения числа и прав. Силы учреждения своевременно рассчитаны не были. Нахлынувшая масса детей парализовала правильность хода дела призрения, в результате - смерть принятых детей, смерть на руках принявших их ради спасения жизни.

По мере того, как такая неудовлетворительность дела призрения в воспитательных домах проявлялась все более и более, начальством заведений принимались меры к ограничению числа приносимых детей. Большинство этих мер были паллиативными, лишь условно влиявшими на уменьшение приноса детей; такое уменьшение проявлялось обыкновенно короткое время после издания новых правил и вскоре, через год или два, по мере приспособления к ним публики, принос снова возрастал: научались обходить стеснение, или же само начальство отказывалось от издаваемых стеснительных условий приема.

Указ 1837 г. о воспитании всех питомцев исключительно в деревнях в своей основе имел целью удержать родителей от отдачи детей в Воспитательный дом, прекративший со времени этого указа заманчивое воспитание из них свободных художников и т.п. С течением времени, когда, несмотря на новое направление в устройстве участи питомцев, принос детей продолжал угрожать своим прогрессивным ростом, начальство воспитательных домов предполагало повлиять на уменьшение приноса детей изданием новых правил приема и возврата детей, по которым (с 1869 г.) дети до годового возраста принимались во всякое время дня и ночи с тем, чтобы те, у которых уже отпала пуповина, 
были приносимы в дом непременно уже крещенными и с метрическою выпиской об их рождении и крещении, в запечатанном или в незапечатанном конверте, (по желанию приносительницы), дети же, у которых еще не отпала пуповина, могли быть приносимы и без метрической выписки об их рождении и крещении; но зато дети, принятые в дом некрещеными, возвращаются приносителям или родственникам только в течение шести недель со дня приноса их в дом, тогда как дети, принесенные в дом крещенными, возвращаются матерям или родственникам во всякое время, хотя и с возмещением Воспитательному дому всех расходов по содержанию ребенка как в самом доме, так и в деревне.

Этими же правилами запрещалось выдавать сведения о месте воспитания в деревне принятого ребенка, время от времени можно было узнавать лишь, жив он или умер. В основе этих суровых, недолго действовавших правил было предположение, что в воспитательные дома будут отдаваться по преимуществу только объявленные (при крещении) незаконнорожденные дети, матери их, хотя и с материальными расходами, всетаки могут всегда возвратить их к себе. Поторопившиеся же отдать до отпадения пуповины, в течение первых 5-6 дней по рождении, после шестинедельного срока теряли всякое право на возвращение когда-либо своего ребенка, он делался тем «казенным» ребенком, каким считают крестьяне и до сих пор всякого питомца. Желанного результата правила эти не принесли, а между тем наводнили дом детьми раннего возраста: большинство спешило отдать до отпадения пуповины, чтобы избавиться от излишних хлопот и расходов по «выправлению» метрики у священников. Чтобы не потерять из виду отдаваемого ребенка, мать его поступала одновременно (под чужим иногда именем) в кормилицы, делая на теле ребенка различные отметки чернилами, ляписом, ожогами и т.п., или прибегая к подкупу других кормилиц или нянек. Принятые же в возрасте от 1 до 6 дней дети составляли 80\% всех принятых, и неминуемо повлекли за собой увеличение процента смертности: возраст их был слишком ранний, чтобы выносить условия их вскармливания сменными кормилицами, с прикормом при частом недостатке последних. Ранний возраст принятых детей увеличивал другую причину усиленной смертности - скученность, так как вызывал необходимость пребывания их в доме до отправления в деревню в течение 3-6 недель, а в случае заболевания и долее.

Не принеся с собой никакой пользы для заведения и вызывая своею суровостью недовольство в обществе, правила эти, 24 апреля 1882 г. утвержденным положением обоих присутствий Опекунского Совета, были изменены в том направлении, что при возврате детей, принесенных в Воспитательный дом крещенными, никакой платы за их содержание в Доме и в деревне не требовалось, и самим матерям предоставлялось даже право за вознаграждение, в половинном размере против наемных кормилиц, кормить в Воспитательном доме своих детей до 6-недельного возраста, а в уважительных случаях разрешалось матерям вскармливать своих детей на дому собственною грудью в течение 6 недель с платою по 35 к. летом и 30 к. зимою в сутки; после 6 недель ребенок должен быть доставлен в Воспитательный дом для отправки в деревню; по желанию мать может воспитывать ребенка на дому и до 3-летнего возраста с производством за такое кормление своих детей в первом году по 30 к., во втором по 20 к. и в третьем по 10 к. в сутки. После 3 лет плата прекращается. 
Первая мера установлена была в тех видах, что многие матери и родственники не брали из Воспитательного дома несчастнорожденных детей единственно только потому, что не имели возможности внести причитающуюся за содержание ребенка плату; вторая же мера имела в виду привлечь матерей к кормлению в Воспитательном доме своих детей в течение 6 недель, чтобы дать ребенку возможность окрепнуть на материнском молоке и таким образом предупредить между детьми первого возраста значительную заболеваемость и смертность, происходящую большей частью от того, что грудные дети в первые дни своей жизни переходят от одной кормилицы к другой, нередко с несоответствующим их организму молоком, а главным образом для того, чтобы поддержать и развить чувства матери в таких женщинах, которым в силу обстоятельств приходится расставаться со своими детьми: имелся в виду при этом и больший возврат детей из Воспитательного дома. С этою же целью новыми правилами разрешалось матерям и родственникам отданных в Воспитательный дом детей получать о них справки, живы ли они и у кого, и в каких деревнях воспитываются, чего прежде не дозволялось.

Выдачу вознаграждения за 6-недельное вскармливание на дому пришлось скоро отменить, так как вместо матерей выискалось много акушерок-посредниц по отдаче детей в Воспитательный дом, удерживавших у себя детей до 6 недель с целью получения обещанного вознаграждения и доводивших за это время своих питомцев до последней степени истощения. Случаев оставления у себя на воспитании до 3-летнего возраста в Московском Воспитательном доме почти совсем не встречалось, в Петербургском же эта система имела некоторый успех.

Кроме изыскания мер к уменьшению приноса детей, воспитательным домам приходилось расширять дело надзора за увеличивающимся числом питомцев в деревенских округах. По мере год от году увеличивавшегося числа детей, подлежавших раздаче крестьянским воспитательницам, приходилось увеличивать район деревенских округов, в состав которых для Московского Воспитательного дома вошли селения Московской, Смоленской, Калужской, Тульской, Владимирской, Тверской и Рязанской губерний. Число округов здесь возросло до 22 с подразделением на 41 участок, находящийся каждый в заведывании одного окружного надзирателя. Для Петербургского Воспитательного дома по линии Балтийской железной дороги - 6 округов, по Варшавской -4 , по Николаевской -4 и Финляндской - 2 округа, всего 16, разделенных впоследствии на 32 участка.

Чтобы поднять нравственный уровень таких ответственных чиновников, как окружные надзиратели, - этих ближайших опекунов несчастных сирот, в 1870 г. содержание их было увеличено сравнительно с прежним более, нежели втрое. В число окружных надзирателей старались привлечь по возможности более врачей. Для успешности лечения заболевающих питомцев в округах были устроены собственные лазареты, открыты начальные школы, организована отдача питомцев в обучение ремеслам как в столицах, так и к местным мастерам в округах. Последнее обстоятельство было вызвано безотрадным положением достигшего совершеннолетия питомца, без знания какого-либо ремесла поступавшего обыкновенно в батраки к чужой крестьянской семье. Это была единственная карьера для крестьянского воспитанник, за исключением тех более счастливых, которые усыновлялись бездетными крестьянскими семьями или женитьбой принимались в дом. До общей воинской повинности лучший, по-видимому, для них исход - усыновление - не 
всегда был, так сказать, бескорыстен со стороны воспитателя: таким усыновлением питомца мог спасаться от солдатчины родной сын семьи: вот почему ближайшей обязанностью окружных надзирателей было исследование в каждом конкретном случае условий усыновления.

С улучшением надзора за округами, с увеличением числа окружных надзирателей и поднятием их нравственного уровня, мало-помалу уничтожились многие злоупотребления и неустройства. Так как за воспитание каждого питомца выдается ежемесячная плата, составляющая некоторое подспорье в бедной крестьянской семье, то понятно желание иметь у себя во что бы ни стало такого воспитанника, и чем беднее семья, чем несостоятельнее хозяйство, тем неотступнее было такое желание. Но Воспитательный дом отпускал из своих стен грудного ребенка только той женщине, которая имела атрибуты кормилицы, отнюдь не отдавая на так называемое рожковое кормление какой-либо старухе бобылке. При плохом надзоре, или вернее при отсутствии его, заурядным явлением была торговля грудными питомцами, практиковавшаяся у всех застав, через которые отправлялись в округа транспорты таких детей.

Обладавшие атрибутами кормилицы крестьянки являлись в Воспитательный дом за ребенком, получали его без замедления и, доехав до заставы, уступали за известное денежное вознаграждение ожидавшим их здесь женщинам, желавшим получить себе такого прибыльного воспитанника, в надежде, что он как-нибудь проживет месяц, другой, а то можно будет прикинуть еще несколько месяцев, скрыв день его смерти, и за накопившиеся месяцы получить своевременно десяток, другой рублей. Подобная торговля производилась не только у застав, но и в деревнях, так что переход из рук в руки вывезенных из Дома детей был явлением заурядным, безнаказанным. С новым устройством округов каждая кормилица должна была доехать с отпущенным ей ребенком непременно до окружного надзирателя, который таким образом знакомился с нею, как с заявившей себя воспитательницею, и без его разрешения она уже не имела права передать ребенка никому другому, в противном случае привлекалась к законной ответственности, не говоря уже о невозможности злоупотреблять получением платы после смерти питомца, так как теперь окружный надзиратель обязан проверять наличность детей не менее одного раза в два месяца. Торговля детьми сама собою уничтожилась.

Дело организации деревенских округов украсилось учреждением собственных начальных училищ, число которых доходит ныне в Петербургских округах до 100, в Московских до 41. Питомцы, проживающие в селениях, где нет собственных училищ, посылаются в земские и церковно-приходские школы. В деле распространения начального обучения грамоте воспитательным домам принадлежит почетное место, так как требование от воспитателей обучения их питомцев грамоте предъявлялось задолго еще до развития земских школ: за каждого обученного грамоте питомца Воспитательный дом выдавал 10 рублей. С распространением земских и других школ Воспитательный дом стал требовать от воспитателей обязательной посылки в школы не только мальчиков, но и девочек.

Уплачивая ежегодно за воспитание питомцев в крестьянских семьях в общем почтенную сумму в размере более миллиона рублей, оба столичные Воспитательные дома в лице окружных надзирателей имеют своих агентов, наблюдающих за правильностью 
выдачи по принадлежности этих денег. Таким образом, главная функция этих агентов фискальная, выражающаяся в наблюдении за наличностью в местах воспитания питомцев, причем на них возлагаются все обязанности по опеке над детьми. Производя периодические, определенные объезды селений своего округа, окружной надзиратель удостоверяется, во-первых, в нахождении грудных питомцев непременно на грудном вскармливании, обращает внимание на состояние здоровья и уход за ребенком, направляет больных за медицинскою помощью в больницы, знакомится на месте с условиями воспитания и взаимными отношениями в каждом отдельном случае, проверяет в то же время сведения, так или иначе дошедшие до него и касающиеся содержания питомца или поведения его, требует, чтобы питомцы и питомки (достигшие 8 лет) были для обучения грамоте отдаваемы в школы или к учителям, после 12 лет содействует воспитателям в отдаче питомцев в различные местные ремесленные заведения для обучения их мастерству, питомцам не моложе 15 лет позволяет поступать для заработков на фабрики и заводы, а равно приискивать и другие формы заработка. На его же обязанности лежит приписка достигших совершеннолетия к сословиям и усыновление, а также разрешение питомкам вступать в брак.

Из этой характеристики обязанностей окружного надзирателя видно, насколько они разнообразны и вместе с тем обширны. Существенный недостаток в этих обязанностях это сравнительная редкость посещения каждого питомца в отдельности - в два месяца один раз. Если для более взрослых питомцев такое редкое посещение и может считаться достаточным, то для младших, и в особенности грудных, желательно более частое посещение, требовать которого при настоящих границах отдельных округов невозможно, для этого необходимо еще большее увеличение числа надзирателей. Хотя в последние десятилетия воспитательными домами и преследуется желание видеть в среде окружных надзирателей побольше врачей, но число их не возрастает, оставаясь для Московского примерно в половине числа всех 41 надзирателей. Причина этого заключается в самой сущности этих должностей; в них прежде всего нет медицинских обязанностей - нельзя же считать таковыми случайное нахождение за десятки верст от своего местожительства больного питомца, которого он снова увидит не ранее 2 месяцев. Организации амбулатории для больных питомцев достигнуть тоже не представляется возможности при частых отлучках для разъездов по округу; мало того, в этих разъездах они находят чувствительное препятствие вообще к их правильной практической деятельности, а в итоге недовольство самою службою, которую врачи при первой возможности стараются переменить на специальную врачебную, как более удовлетворяющую их призванию.

Организация надзора за питомцами в наших воспитательных домах сравнительно с другими европейскими воспитательными домами представляется все-таки лучшею: там многие дома не в состоянии даже иметь своего надзора и поручают его священникам или сельскому начальству. Только одному Парижскому мы можем завидовать в достигнутой им возможности поручать грудного питомца надзору врача: там окружной надзиратель приглашает частного врача принять на себя обязанность навещать детей в первые два месяца жизни еженедельно и до одного месяца ежемесячно, за свои посещения врач получает повизитную плату, равно и за медицинскую помощь каждому питомцу. Правда такая организация возможна только в департаментах Франции, где во всяком местечке 
налицо несколько врачей служащих или вольно практикующих, так что расстояние между жилищем врача и питомца не превышает 4 верст.

Оставляя за окружными надзирателями их необходимую для воспитательных домов фискальную и опекунскую деятельность, мы не представляем себе возможности идеальной организации надзора за воспитанием питомцев в деревнях, в особенности в грудном их возрасте, при посредстве одних лишь собственных агентов Воспитательного дома. По нашему мнению, залог лучших условий призрения питомцев в деревне - в содействии всего общества, при помощи частной инициативы его членов. Вызвать, привлечь к себе эту инициативу - вот ближайшая задача воспитательных домов. Изолированное положение, занятое ими, излишне формальное отношение к сложному делу устройства участи призреваемых ими детей должны уступить место широкому единению с общественными органами, в сочувствии которых нет основания сомневаться ${ }^{13}$.

\section{VIII}

Итак, христианство научило признавать в ребенке человеческую личность, представители церкви научили заботе о брошенном ребенке, добросердечные люди приняли на себя устройство благотворительных заведений, богатые люди делились с ними средствами, оставалось только развиваться и процветать этому делу милосердия. Но жизненный опыт таких учреждений для брошенных детей, различие взглядов государственных деятелей на воспитательные дома по отношению их к нравственности общества, наконец, социальные и экономические условия с течением времени изменили в самых существенных чертах основной идеал воспитательных домов.

Имея в основе своей предупреждение детоубийства и вытравления плода, все воспитательные дома открыли у себя так называемый «тайный прием» детей. Такой формой приема давалась возможность матери сохранить в тайне самый факт произведения ею на свет ребенка, а так как такой секрет чаще или, вернее сказать, только и необходим в случаях незаконного рождения, то с именем воспитательных домов само собой соединилось представление о воспитании в них незаконнорожденных детей, таких, которые по закону не имеют права ни на имя и фамилию отца, ни на законное после него и даже после своей матери наследство в имуществе.

Если некоторыми воспитательными домами и расширялся район их благотворительной деятельности одновременным призрением сирот и бесприютных законных детей, то эти последние не смешивались с детьми первой категории, они регистрировались особо по их документам, тогда как первые записывались в ежегодном хронологическом порядке поступления и числились под номерами приемной книги. Каждому такому ребенку надевался на шею значок с соответствующим номером, под

${ }^{13} \mathrm{C}$ отменой закона, воспрещавшего открытие воспитательных домов в провинциях, в последнее время во многих городах уже появились подобные учреждения, устраиваемые на частные средства, а некоторые земства занимаются переустройством существовавших домов для подкидышей. Из известных нам таких учреждений назовем - Смоленский, Воронежский, Одесский, Тверской, Бежецкий, Иркутский. 
которым ${ }^{14}$ он и значился во все время нахождения его под покровительством заведения. В редких случаях, с целью повлиять на уменьшение приноса детей, некоторыми воспитательными домами, в том числе и нашими русскими, прекращалась выдача приносителям детей квитанций, по которым всегда есть возможность разыскать ребенка и вернуть его матери или родственникам; впрочем, такие меры всегда были временными, непродолжительными, и скоро отменялись в виду справедливого сетования на них, как не отвечающих законам гуманности.

Практиковавшаяся большинством воспитательных домов система «тайного приема» детей была много раз предметом обсуждения о ее пригодности при настоящих условиях деятельности заведений. В многочисленных комиссиях, учреждавшихся по этому вопросу в Париже, не было недостатка в голосах, как защищавших эту систему, так равно и порицавших ее.

Сторонники системы тайного приема - «tour'a» - постоянно твердят одно и то же: «tour» есть оплот девичьему стыду, «tour» предупреждает детоубийство и аборт. Некоторые же из противников «tour'a» уверяют, что он не только не предупреждает детоубийство, а напротив способствует ему. Они говорят, что в большинстве случаев детоубийство производится матерью при таинственной обстановке, с глаза на глаз с своей жертвой и почти всегда немедленно по произведении таковой на свет. Возможность такого непонятного преступления - отнятие жизни у существа, которому только что сама дала жизнь - объясняется аффектом, имеющим в основе полное истощение физических и нравственных сил, а также вспыхнувший стыд перед семьей и обществом; окружающая же обстановка, полная беспомощность, отсутствие участия, совета и утешения от кого-либо еще более располагают проявить извращенное чувство к виновнику такого состояния невинному младенцу, существование которого до этого момента она в течение всех девяти месяцев так заботливо скрывала и оберегала. Тот «tour», на который она все время своей секретной беременности рассчитывала, оказывается от нее далеким, отнести туда ребенка она не в силах, довериться некому, тут она только познает, что в существовании «tour'a» нет обеспечения абсолютной тайны, необходим был посредник, которого она не догадалась или не могла приготовить; в результате - преступление, начало которому предлагают искать в старательном уничтожении материнского чувства к ребенку за все время беременности. Существование «tour'a» в глазах легкомысленной девушки обеспечивало будущность ее ребенка, она о нем не думала, не заботилась и хлопотала лишь о сокрытии следов своей беременности.

Некоторые из противников «tour'a» видят в существовании его также условие все более и более развивающейся безнравственности общества. По действующим законам Франции (и России) отцы незаконнорожденных детей не ответственны за воспитание и содержание их. Зная, что «tour» в случае надобности может заменить отца, соблазняющий девушку ни на один миг не задумывается о возможных последствиях внебрачного сожития, потребовавших бы при других условиях известных материальных жертв с его стороны. С

${ }^{14}$ Например: $\frac{10121}{1895 \text { г. }}$ или $\frac{10}{1898 \text { г. }}$ 
своей стороны, и девушка легче соглашается на такое внебрачное сожитие, зная, как легко и просто воспользоваться услугами «tour'a», когда представится необходимость отделаться от последствий своего увлечения. Что же касается до ее естественного материнского чувства, то оно прерывается тотчас по рождении ребенка представлением о тайной приемной, куда спешат отправить ее новорожденного. Оставшись без ребенка, без забот о кормлении и уходе за ним, чувствуя свое полное благополучие при существовании такого благодетельного, как «tour», учреждения, она уже не задумывается над участью своего второго ребенка, а при случае не замедлит поделиться своим знанием и опытом с своей подругой. Если бы, говорят противники «tour'a», материнскому чувству дано было должное развитие, ребенок остался бы при ней, в этом был бы залог поправки сделанного ею ложного шага, легко могло бы случиться, что рожденный ребенок заставил бы мать и отца взглянуть более серьезно на их увлечение, на их случайную связь и повлечь за собой семейную жизнь, составляющую оплот нравственности общества.

Тайному приему, кроме того, делают упрек еще за то, что в нем нередко лежит залог преждевременной смерти приемыша. Природа указала матери кормить рожденного ею ребенка своим молоком. Значение этого удивительного продукта - материнского молока настолько велико для питания новорожденных, что, несмотря на все успехи современной науки, до сих пор еще никому не удавалось заменить его искусственно; ребенок, лишенный этого естественного питания, тем более теряет шансы на продолжение своей жизни, чем менее похож заменяющий материнское молоко суррогат его.

Служа защитой девичьему стыду, «tour» является подчас участником преступления против законных прав ребенка. В такую гостеприимную корзину может попасть всякий ребенок: и тот, который действительно не имеет ответственного за свое воспитание отца незаконнорожденный, и тот, родители которого из бедности, скупости, или просто каприза пожелают отделаться от своих естественных обязанностей, и, наконец, тот законный ребенок, рождение которого пожелают скрыть из каких-либо корыстных и иных целей родственники или даже посторонние люди. Сохраняя тайну родов девицам или вдовам, тайный прием, как мы сказали, дает возможность безнаказанно производить преступления, караемые общими законами.

Самым существенным недостатком тайного приема является возможность чрезмерной, безграничной эксплуатации им, ставящей администрацию заведений в невозможность исполнять взятую на себя задачу. Все воспитательные дома Европы, где существует тайный прием, в один голос протестуют против этих условий, вызывающих нарекания на их деятельность из-за громадного процента смертности принятых ими детей. Как бы велики ни были материальные средства учреждения, если оно не гарантировано известным комплектом призреваемых, известным районом своего благотворения, оно не может предвидеть всех последующих за этим неудач своей деятельности. Мы видели, как неудержимо возрастало число призреваемых в Московском Воспитательном доме, как безуспешно боролись против этого различными паллиативными мерами, в конце концов, пришлось позаботиться об ограничении приема детей в воспитательные дома путем радикального изменения свыше столетия действовавших правил приема детей. 
С 1891 года в наших столичных Воспитательных домах установлена система явного приема младенцев. Считаем нелишним привести здесь эти правила полностью.

$\S 1$. В Императорские, Московский и С.-Петербургский, Воспитательные дома дети принимаются на призрение и временное вскармливание.

$\S 2$ В означенные Дома принимаются в возрасте не старше года: а) незаконные младенцы, лишившиеся матерей; б) незаконные младенцы таких матерей, которые или по беспомощности, или по необходимости сохранить тайну рождения ребенка, не могут держать его при себе, и в) подкидыши, никем не принятые на воспитание.

§ 3. При приеме незаконного младенца требуется: I) выписка из метрических книг о его рождении и крещении; II) удостоверение личности, или вид на жительство лица, принесшего младенца; III) в случае смерти матери - законное о том удостоверение.

Младенцы, принесенные с этими документами, принимаются бесплатно.

§ 4. Незаконный младенец может быть принят с метрическою выпиской в запечатанном конверте, с собственноручною на нем надписью священника: «выписка из метрической книги о рождении и крещении незаконного младенца (имя рек, но без фамилии), родившегося (такого-то года, месяца и числа), выданная (такой-то) губернии, (такого-то) уезда, (такого-то) города или села, священником (такой-то) церкви (имя рек); затем, подпись священника и церковная печать.

При приеме младенца с запечатанной метрическою выпиской требуется: I) удостоверение личности или вид на жительство лица, принесшего младенца, и II) взнос не менее двадцати пяти (25) руб. Деньги, вносимые свыше этой суммы, поступают в обеспечение будущности младенца.

$\S 5$. В случае необходимости сохранения тайны, допускается принятие ребенка без документов, требуемых $\S 3$ и 4 правил, но с предъявлением особого удостоверения от приходских священников и от лиц, стоящих во главе советов и комитетов благотворительных обществ, имеющих утвержденные установленным порядком уставы, а также от Директоров родовспомогательных заведений Ведомства Учреждений Императрицы Марии. С разрешения Почетных Опекунов, управляющих Императорскими Воспитательными Домами, прием младенцев, в особо уважительных случаях, допускается и без указанного в сем параграфе особого удостоверения.

Как в том, так и в другом случае обязательно вносится не менее пятидесяти (50) рублей. Деньги, вносимые свыше этой суммы, поступают в обеспечение будущности младенца.

$\S$ 6. Подкидыши принимаются исключительно чрез полицию при письменном от нее удостоверении, что младенец подкинут неизвестным и что о родителях его производится установленное расследование.

§ 7. Из правительственных и общественных родовспомогательных учреждений и больниц беспрепятственно принимаются, на временное кормление, младенцы в грудном 
возрасте, как незаконные, так и законные, если мать там умерла, или, по удостоверению медицинского начальства учреждения, не может кормить грудью.

В таких же случаях принимаются младенцы из частных родильных приютов и от повивальных бабок, но притом не иначе, как при полицейском свидетельстве о том, что мать младенца умерла, или что она, по удостоверению врача, по болезни кормить грудью не может.

Примечание. Таковой прием на временное кормление допускается от таких лишь родовспомогательных учреждений и повивальных бабок, которые примут на себя обязательство своевременно уведомлять начальство Воспитательного дома о предстоящей выписке выздоравливающей матери, для возврата ей ребенка, принятого на временное кормление.

Равным образом, эти учреждения и лица обязываются уведомлять начальство Воспитательного дома, с представлением установленного свидетельства о смерти родильницы принятого на временное кормление младенца. В случае неисполнения такими учреждениями или повивальными бабками означенных обязательств, младенцы впредь от них не принимаются.

$\S 8$. Оставление на дальнейшее призрение младенцев, принятых, по § 7, на временное кормление, зависит от признания их начальством Воспитательного дома, на основании доставленных документов, соответствующими условиям приема, изложенным в $\S \S 2,3,4,5$ и 9 правил. Дети, признанные несоответствующими условиям дальнейшего призрения их в Воспитательном доме, возвращаются выздоровевшим матерям до выписки сих последних из родовспомогательных учреждений, больниц или повивальных бабок.

§9. Законные младенцы, не старше десяти месяцев, допускаются на временное кормление до годичного возраста в тех случаях, когда мать ребенка умерла или так больна, что не может кормить грудью, а ребенок не может быть вскормлен на средства родителей.

При этом должны быть представлены следующие документы: I) метрическая выпись о рождении и крещении младенца; II) удостоверение о смерти матери, или медицинское свидетельство о ее болезни, препятствующей ей кормить грудью; III) свидетельство от приходского священника или от церковно-приходского попечительства, братства или благотворительного общества о неимении возможности вскормить ребенка на средства родителей.

По достижении отданным в Воспитательный дом законным ребенком годового возраста, он возвращается на попечение родителей.

В случае невзятия в срок родителями своего ребенка, они понуждаются к тому через полицию, причем взыскиваются с них, исполнительным порядком, на основании примечания к ст. 1 Уст. Гражд. Суд., изд. 1892 г., издержки за содержание ребенка со дня достижения им годичного возраста.

$\S 10$. Лицу, принесшему младенца, выдается билет в принятии от него ребенка, с обозначением номера, под которым ребенок записан, и времени приноса. 
$\S 11$. Мать принятого в Воспитательный дом младенца, выразившая желание кормить его грудью и подходящая под условия для кормилиц, обязательно допускается к тому начальством Воспитательного дома.

$\S 12$. При приносе младенца с документами, указанными в $\S 3$, начальство Воспитательного дома вправе требовать, чтобы мать принесенного младенца, если подходит под условия для кормилиц, сама поступала в Воспитательный дом для кормления грудью своего ребенка. Если она откажется от исполнения этого требования по причине, признанной начальством Воспитательного дома неуважительною - ей может быть отказано в приеме младенца.

$\S 13$. Кормление матерью своего ребенка грудью в Воспитательном доме продолжается, насколько это будет признано начальством заведения возможным. При этом матери производится установленное для кормилиц в Воспитательном доме жалованье и довольствие.

$\S 14$. Если мать, кормящая своего ребенка в Воспитательном доме, пожелает продолжать грудное кормление его у себя на дому, в С.-Петербурге или Москве или же в пределах округов Воспитательных домов и, затем, оставить его окончательно на своем попечении - то ребенок может быть отдан ей, по усмотрению начальства Воспитательного дома, с производством вспомоществования до достижения ребенком двухлетнего возраста, причем по С.-Петербургскому Воспитательному дому за ребенка в возрасте до 1-го года матери выдается по тридцати (30) коп., а в возрасте от 1 до 2 лет - по двадцати (20) коп. в день, а по Московскому - в первом случае по двадцати пяти (25) коп. в день, а во втором по семнадцати (17) коп. в день, а в округах - установленная плата воспитателям за питомцев этого возраста. По достижении двухлетнего возраста, ребенок окончательно поступаете на полное попечение матери.

Производимое матери вспомоществование может быть прекращено: I) если она дурно содержит ребенка; II) в случае предосудительного ее поведения, и III) если окажется, что, по изменившимся обстоятельствам, она в пособии не нуждается.

В первых двух случаях, равно как в случае смерти матери, ребенок может, по усмотрению начальства Воспитательного дома, быть принят обратно в Воспитательный дом.

$\S 15$. Некрещенные дети подлежат крещению при приеме и воспитываются в православной вере. Питомцы возвращаются только лицам христианского вероисповедания.

$\S 16$. Питомцы Императорских Воспитательных домов, не усыновленные на основании существующих законоположений, могут быть возвращаемы в установленные § 17 сроки: I) матерям по их просьбе, или, с их согласия - другим лицам; II) в случае смерти матери - родственникам по их просьбе; III) принятые на основании $\S 4$ и 5 правил предъявителям билетов (§ 10); IV) подкидыши возвращаются чрез полицию, когда будут отысканы лица, обязанные иметь попечение о ребенке.

$\S 17$. Питомцы Императорских Воспитательных домов могут быть возвращаемы в следующие сроки: I) дети, которых кормили грудью их матери в Воспитательном доме, 
возвращаются до семилетнего возраста, без всякой платы; II) дети, которых не кормили грудью их матери в Воспитательном доме, возвращаются до трехлетнего возраста бесплатно; по истечении же означенного возраста (но не свыше семилетнего возраста), лишь по уплате Воспитательному дому десяти (10) рублей за каждый год содержания ребенка, со дня наступления ему трехлетнего возраста; IV) после семилетнего возраста, питомец может быть возвращен только в исключительном случае, по усмотрению начальства Воспитательного дома, при условии уплаты Воспитательному дому за каждый год содержания ребенка, сверх срока, до которого он возвращается бесплатно (п.п. I и II сего §) - по десяти (10) руб. в год.

Подкидыши возвращаются во всякое время, без ограничения срока, но лишь чрез полицию, когда отысканы родители подкидыша, причем Воспитательный дом взыскивает исполнительным порядком, на основании примеч. к ст. 1 Уст. Гражд. Судопр. изд. 1892 г., на покрытие издержек по содержанию ребенка, тридцать (30) рублей за каждый год.

$\S 18$. Для возврата из Императорских Воспитательных домов питомцев, принятых на основании §3 правил, должны быть предъявлены следующие документы: I) билет, выданный при приеме младенца (§ 10); II) паспорт лица, которому возвращается ребенок; III) в случае возврата ребенка постороннему лицу - надлежащим образом удостоверенное письменное заявление матери о согласии на передачу ему ее ребенка; IV) в случае смерти матери ребенка - законное о том удостоверение.

Питомцы, принятые на основании $\S 4$ правил, возвращаются по предъявлении билетов, выданных при их приеме (§ 10), и паспорта лица, коему возвращается ребенок.

Питомцы, принятые на основании $§ 5$ правил, возвращаются по предъявлении одних билетов, выданных при их приеме (§ 10).

$\S 19$. Питомцы, взятые матерями из Воспитательного дома и принесенные впоследствии вторично, принимаются вновь не иначе, как в исключительных случаях, по усмотрению начальства Воспитательного Дома, хотя бы подходили под общие условия приема.

$\S 20$. Опекунскому Совету Учреждений Императрицы Марии предоставляется изменять размер установленных денежных взносов при приеме и возврате детей по $\S 4,5$ и 17 правил.

Со введением в действие этих новых правил приема, условия деятельности воспитательных домов резко изменяются во всех направлениях.

В основу новых правил легло строгое определение назначения воспитательных домов для призрения одних лишь незаконнорожденных детей и подкидышей. Чтобы был бесплатно принят на полное воспитание ребенок, требуется представление метрической выписки о его рождении, удостоверяющей, что он - незаконнорожденный. Чтобы дать возможность сохранить тайну рождения ребенка, предоставляется право эту метрическую выписку представлять в запечатанном конверте с надписью на нем священника, что выписка сия принадлежит незаконнорожденному ребенку такому-то (имя) без упоминания 
о матери ${ }^{15}$. Наконец, для исключительных случаев, когда и метрическая выписка для матери - дело трудное, ей предоставляется право представления удостоверения о незаконнорожденности ребенка от кого-либо из лиц, стоящих во главе советов и комитетов благотворительных обществ, а также директоров родовспомогательных заведений и приходских священников. Кроме того, в особо уважительных случаях, почетные опекуны воспитательных домов могут лично разрешать прием без всяких документов - без метрики и без удостоверения. Подкидыши принимаются только через полицию, так как допустить прием их от частных лиц рискованно в виду возможных злоупотреблений.

Этими условиями приема прежде всего парализуется возможность сбывать в воспитательные дома законных детей. Гражданские права их теперь не могут уже быть нарушаемы по произволу родителей и при невольном участии в том самих воспитательных домов. Правда для таких безнравственных и бессердечных родителей остается лазейка в воспитательный дом - подкидывание, но, во-первых, этот акт сам по себе грубее сравнительно с дозволявшимся приносом ребенка в приемную дома, а, во-вторых, подкидывание есть преступление, и в случае его обнаружения виновник является ответственным перед законами.

Посмотрим, как отразились эти новые правила на приносе детей в воспитательные дома. В то время как при прежних правилах число ежегодного приноса в последние годы достигало 16-17 с лишком тысяч в один Московский, в течение 1892, 93, 94 и 95 годов оно падает до 10 700, 10 600, 9800 и 9 700. Убавление детей на семь, восемь тысяч в год - факт, имеющий весьма существенное значение для условия призрения, отразившийся, как мы увидим ниже, на всем ходе дела. Стало быть, с точки зрения воспитательных домов это ограничение функций домов приемом одних лишь незаконных детей неоспоримо акт существенной важности, облегчающий его задачу.

По этим же правилам матерям, желающим вскармливать своих незаконнорожденных детей у себя на дому, предлагается денежная помощь в течение первых двух лет. С развитием такой новой системы призрения незаконнорожденных детей, число поступающих на попечение воспитательных домов должно еще более уменьшиться, увеличив число обеспеченных незаменимым материнским участием в их воспитании.

Чтобы улучшить быт детей, принятых в дом, - а это всецело зависит, как мы видели, от наличности кормилиц и притом хороших, годных для новорожденных, - в новых правилах мы встречаем параграф, по которому Воспитательному дому предоставляется право требовать, чтобы мать принесенного ребенка оставалась его кормить, с производством ей жалованья наравне с наемными кормилицами. Опять-таки, с точки зрения воспитательных домов, этот параграф должен бы в высшей степени благотворно отразиться на деле призрения детей. В самом деле, мало того, что детей на целых семь

${ }^{15}$ В этом последнем случае требуется денежный взнос в размере 25 рублей. 
тысяч стало меньше, но у половины ${ }^{16}$ всех принятых обеспечено грудное их вскармливание и притом молоком их собственных матерей.

Какие же результаты получились в стенах воспитательных домов при этих новых условиях призрения детей.

1) При условии обеспечения грудного кормления кормилицами-матерями более половины всех детей и одновременном уменьшении наличности детей, воспитательные дома могут теперь удлинять срок пребывания детей в своих центральных заведениях. Это обстоятельство в наших глазах имеет громаднейшее значение для последующих условий призрения детей в деревнях. 53\% отправлявшихся прежде в деревни в раннем возрасте 3-2 недель уступает место 68\% вывезенных в 1894 г. детей в возрасте 6 и старше недель, притом в состоянии питания и развития значительно лучшем в силу пользования многими из них за время пребывания в доме грудным молоком своих матерей, а не частичкой молока случайной кормилицы. Отпуск в деревенские округа детей в таком сравнительно старшем возрасте, при лучшем состоянии сил и питания, a priori уже должен отразиться на проценте смертности в деревнях детей в возрасте до одного года - и действительно, будучи по отчету 1887 г. равным 48,5\%, он упал в 1894 г. до $37,6 \%$.

2) Вместе с тем возможность удерживать детей до 6-недельного возраста, да притом при наличности самих матерей, могущих быть подробно исследуемыми, дает более прочную точку опоры для обнаружения врожденного сифилиса и тем самым низвести до minimum'a случаи отправки к деревенским воспитательницам питомцев с непроявившейся в стенах Дома этою болезнью. Все дети, у которых обнаружена эта болезнь или только подозревается, задерживаются в Доме и вскармливаются, если у них нет родных матерей, искусственно, сифилитики же также и наличными, заведомо с этою целью принятыми, кормилицами-сифилитичками. Небольшой процент подозрительных на сифилис детей, если у них в течение 3 месяцев не выразится сифилис, хотя и отправляется в деревни, но при соблюдении непременного условия на рожковое кормление, и в деревни одного из округов, расположенных в ближайшем расстоянии от сельской лечебницы Воспитательного дома, на врача которого возлагается обязанность особого за ними наблюдения.

3) В лице матерей-кормилиц, пожелавших после отдачи ими своих детей деревенским воспитательницам остаться в кормилицах Воспитательного дома, имеется контингент таких кормилиц, срок родов и качество молока которых являются не гадательными или случайными, а хорошо известными, и они могут служить для врачей большим подспорьем в различных случаях, требующих именно таковых кормилиц.

4) Что касается влияния новых правил на процент смертности среди призреваемых в доме, до отправления их в деревни, то оно отразилось уменьшением смертности лишь в первые годы по введении новых правил. Возросши до 48,8\% в 1889 году, в года, после введения правил, процент смертности выразился так:

\footnotetext{
${ }^{16}$ Из всех принятых в 1895 г. в Московский Воспитательный дом 9787 детей 4549 кормились грудью своих матерей.
} 


\begin{tabular}{c|c|c|c}
\hline $\begin{array}{c}\text { Процент } \\
\text { смертности }\end{array}$ & $\begin{array}{c}\text { Среди всех } \\
\text { призреваемых детей }\end{array}$ & $\begin{array}{c}\text { Среди детей, } \\
\text { вскармливаемых родными } \\
\text { матерями }\end{array}$ & $\begin{array}{c}\text { Среди детей, } \\
\text { вскармливаемых } \\
\text { случайными кормилицами }\end{array}$ \\
\hline в 1893 г. & $28,4 \%$ & $19,2 \%$ & $33 \%$ \\
в 1894 г. & $32,9 \%$ & $20,3 \%$ & $44 \%$ \\
в 1895 г. & $27,1 \%$ & $16,3 \%$ & $37 \%$ \\
в 1896 г. & $39,9 \%$ & $25,5 \%$ & $50,1 \%$ \\
в 1897 г. & $32,2 \%$ & $19,5 \%$ & $43,7 \%$ \\
в 1998 г. & $41,5 \%$ & $23,8 \%$ & $56,9 \%$ \\
\hline
\end{tabular}

Здесь мы встречаемся с роковым влиянием совокупности условий, от которых зависит смертность детей в воспитательных домах. В числе этих условий мы не раз отмечали скученность и недостаток кормилиц. Несмотря на значительное уменьшение приноса детей, их ежедневная наличность, так называемое среднее пребывание каждого ребенка в доме, - нисколько не уменьшилось, напротив, при требовании от матери кормить своего ребенка в течение шести недель, оно должно было увеличиться: отсюда скученность в несоответствующем наличности детей помещении, в 1898 г. в среднем ежедневно было 1104 ребенка. Недостаток кормилиц в свою очередь не перестает давать себя знать во внушительной для того же 1898 года цифре средней ежедневной наличности 336 кормилиц. Вместе с тем надо отметить факт все более и более уменьшающегося притока желающих брать на воспитание в деревни: вместо являвшихся в прежние годы 10-12 тысяч таковых в 1898 году было всего 5505.

Итак, мы видим, что новые правила приема во многом облегчили задачу воспитательных домов: они, прежде всего, несомненно уменьшили число призреваемых и обеспечили для многих из них материнское грудное кормление в первые недели их жизни - такова оценка их с точки зрения воспитательных домов. Что же касается общественной точки зрения, то здесь мы встречаемся с недовольством на эти правила, в основу которого очевидно легло нежелание расстаться с системой тайного приема.

Прислушаемся к тем нареканиям, которые высказываются по адресу новых правил приема детей в воспитательные дома.

Говоря о требовании за воспитание ребенка непосильной для большинства матерей 25-рублевой платы, умышленно или по незнанию отождествляют это требование для всякого подаваемого в дом ребенка. Мы уже сказали, что прием ребенка, незаконнорожденность которого удостоверена, непременно бесплатный. Плата требуется в случае, когда мать, желая сохранить тайну, не является сама в воспитательный дом и отправляет туда ребенка с метрикою в запечатанном конверте. Но так как воспитательные дома теперь требуют от матери кормление ею самою ребенка в течение не менее 6 недель, а это обстоятельство многим из матерей представляется стеснительным чисто из материальных расчетов, то они, не будучи в состоянии ценою 25 рублей откупиться, так сказать, от этого требования, и ратуют против такой стеснительной для них меры, отнимая от нее тот принцип, на котором она построена, т.е. запечатанный конверт - для ограждения женского стыда, сокрытия тайны рождения и имени матери. Более высокий денежный взнос для того и назначен, чтобы запечатанным конвертом не стали пользоваться и все те, которым вовсе не нужна тайна, а лишь бы не оставаться в воспитательном доме и вернуться к своим прерванным родами занятиям на фабрике или в услужении. 
Другое недовольство - ежедневно публикуемые случаи подкидывания. Факт несомненный, что с введением новых правил число подкидышей, препровождаемых, например, в Московский Воспитательный дом, с нескольких десятков в год возросло в 1895 г. до 685. Обстоятельство это не было неожиданностью, оно предвиделось при выработке новых правил приема. Причины, объясняющие этот грустный факт, следующие.

Нам известно полное незнакомство с новыми правилами многих интеллигентных лиц столицы; отсюда легко себе представить, насколько они мало известны и превратно толкуются в далекой деревенской глуши (а между тем по статистике 30\% приносимых детей принадлежат рожденным в других губерниях). При этих условиях возможно безвыходное положение женщины, взявшейся доставить в воспитательный дом из деревни ребенка, не запасаясь требуемыми для приема его документами; отказ в приеме такого ребенка вынуждает ее отделаться от принятого поручения подкидыванием.

При непроницаемости такого таинственного преступления, как подкидывание, конечно, трудно проникнуть в истинную причину каждого конкретного случая, но можно, в виду резкости увеличения факта, предположить, что новые правила, закрыв двери семи, восьми тысячам прежде подававшимся в Московский Воспитательный дом детям под видом незаконных, заставляют теперь часть из них подкидывать, в особенности, когда ребенок рождается замужней женщиной, живущей в разлуке с мужем. Подкидываются, вероятно, также и те дети, матери которых не желают или не могут оставаться кормилицами в Воспитательном доме.

Наконец, в числе подкидышей несомненно находятся и такие, которые бросались родителями и при существовании тайного приема, по причинам, объяснить которых мы не в силах.

Но если грустный факт увеличения числа подкидышей в Москве приблизительно до двух случаев в день сопоставить с семью тысячами детей, остающихся ныне, благодаря новым правилам, у своих законных родителей, сохраняя все свои гражданские права, в обстановке, вернее обеспечивающей их жизнь, чем прежнее их поступление почти на верную смерть от голодания в Воспитательном доме, то факт этот в наших глазах теряет то ужасающее значение, которое спешат ему приписать. Доставляемые в Московский Воспитательный дом подкидыши по своему состоянию здоровья вовсе не представляют собою существ, подвергавшихся тяжелым испытаниям с момента их подкидывания до приема в Воспитательный дом: очевидно, время их пребывания без призора и кормления не бывает продолжительным. Процент смертности подкидышей в 1895 г. был равен 33\%, немногим выше процента смертности того числа детей, которые, находясь при одинаковых условиях, кормились так же, как и они, наемными кормилицами.

Конечно, мы не станем отвергать необходимости считаться с фактами, нарушающими строй общественной жизни, возмущающими общественную совесть. Из сказанного ясно, что случаи, требующие непременной помощи бедной матери и ее законному ребенку, действительно возможны и существуют, но из этого не следует возлагать эту обязанность непременно на два воспитательных дома; для таких случаев рядом с ними должны явиться специальные для этой цели учреждения, начало которым уже 
положено в Москве Елизаветинским благотворительным обществом, призревающим ныне до нескольких сот законных детей бедных родителей.

Мы уже сказали, что горький опыт всех воспитательных домов заставил их отказаться от воспитания своих питомцев в стенах своих заведений. Времена, когда из питомцев хотели, а может быть и могли (при их небольшом числе), создавать так называемое третье сословие - tiers état - миновали; воспитание в крестьянских семьях мастера, фабричного или пахаря, вот теперешний удел всех принимаемых воспитательными домами детей. Отдавая питомца в крестьянскую семью, воспитательные дома преследуют непрерывную связь данного питомца с семьей его кормилицы. Насколько такая связь достижима, показывает бесконечный ряд примеров, заставляющих преклоняться перед сердечностью и добродушием русского крестьянина. Сплошь и рядом старик-дед запамятовал, который из двух внуков родной и «питомок», сплошь и рядом встречается забота старухи-бабушки, воспитательницы, вернутся ли к ним их питомцы из солдатчины; степень сродства семьи с питомцем ясно сказывается в отсутствии браков питомцев с дочерями их воспитателей или их сыновей с питомками: они считаются братьями и сестрами по груди, по семье. Такую форму призрения брошенному родителями сироте, «казенному ребенку», дает семья; случайно делаясь членом ее, он сливается с ней, делит ее радости и горе и, может забыть, в конце концов, свое одиночество. Дать этого никакая другая форма призрения не может.

Недостатки деревенского воспитания главным образом сказываются лишь в периоде раннего детства, в грудном возрасте. Это - самая больная сторона дела. В основе лежат вековые антигигиенические условия, окружающие крестьянского сосунка. Единственно, что возможно и что действительно требуется воспитательным домом, это непременное грудное вскармливание питомца. Новые правила приема, уменьшившие и число отдаваемых в деревни детей, дали возможность требовать, чтобы приходящая за ребенком кормилица имела удостоверение от окружного надзирателя, что она, во-первых, берет именно себе или для известной надзирателю другой кормилицы и что она своего ребенка откормила три поста или он умер - словом, преследуется, чтобы не было параллельного грудного кормления, чтобы им не обделялся ни родной ребенок, ни питомец. Эти же условия позволяют теперь требовать, чтобы на одно и то же молоко, т.е. одной и той же кормилицы, в случае смерти первого питомца не поступало более чем двум детям. Нельзя не приветствовать меры, клонящейся к урегулированию кормиличного промысла в смысле защиты родных детей. Это, по нашему мнению, первый шаг к так называемому «закону Русселя» французов, по которому ни одна мать не может брать на себя обязанности кормилицы, если ее ребенок жив, и она его не откормила в течение 7 месяцев.

Перейдя за рубеж годового возраста, питомец переживает обыденное крестьянское детство. По достижении 8 лет он обязательно должен быть обучаем грамоте (равно как и питомки), в случае отсутствия вблизи школы он обучается за счет Воспитательного дома; далее, воспитателю предоставляется право помещения его для обучения мастерству у кустарей или в столичных ремесленных заведениях. С прекращением платы за воспитание (с 15 лет) питомцам дозволяется поступать на заработки. Опека Воспитательного дома над питомцами прекращается, когда они усыновляются своими воспитателями или посторонними или приписываются по достижении совершеннолетия к крестьянскому 
обществу или в мещанское сословие, а питомки - когда выходят замуж или приписываются тоже к мещанскому сословию.

Констатируя факт несомненного благотворного влияния новых правил на условия призрения детей в наших воспитательных домах, мы далеки от мысли видеть в них одних разрешение всех неблагоприятных сторон этого сложного дела, но мы уверены, что они, выведя из безвыходного положения два столичных воспитательных дома, представляют собой первый шаг к дальнейшему урегулированию этой важной отрасли общественного призрения.

Нельзя закрывать глаза от явления, с каждым днем захватывающего собой все больший и больший круг человеческого общежития: никто не станет отвергать факта увеличения у нас числа незаконнорождаемых детей ${ }^{17}$, никто не станет возражать против необходимости устройства участи таких детей, у которых нет юридического отца; 542 ст. VIII т. Св. Зак., запрещавшая открытие воспитательных домов в губерниях, очевидно имела, между прочим, и цель остановить рост незаконнорождений, а так как жизнь показала противное, то состоявшаяся отмена этого закона представляется вполне основательной. Следом за этим должна совершиться децентрализация столичных воспитательных домов, ибо нет никакого основания сосредоточивать призрение незаконнорожденных детей всего государства в двух столичных заведениях: при такой форме одинаково страдают как пересылаемые в эти заведения дети, так и сами заведения, переполняясь этим пришлым издалека элементом. В нашу задачу не входит оценка степени участия в такой децентрализации государства, общественных органов и благотворительности, мы лишь с уверенностью говорим о необходимости ее ради самого дела.

На основании всего здесь изложенного мы можем сделать следующие выводы.

При наличности повсеместно незаконнорожденных детей, приюты для них необходимы, так как такие дети представляют собою наиболее обездоленные существа.

Независимо от таких приютов, в подобных же приютах могут нуждаться и законные дети бедных родителей. В больших центрах эти два типа приютов должны быть разделены.

Одно лишь грудное вскармливание может обеспечивать сохранение жизни грудному ребенку-приемышу. Участие в этом матерей, хотя бы первые 6 недель, повышает шансы на сохранение жизни.

Денежная помощь матерям, желающим воспитывать своих незаконнорожденных детей на дому, должна занять видное место в ряду условий, обеспечивающих успех благотворительной деятельности воспитательных домов.

17 В пятидесяти губерниях Европейской России ежегодное число незаконнорождений в последние годы колеблется между 107750 и 117 790. В Петербурге из 1000 первородящих более 2/5 рождают вне брака, а в 1898 году процент незаконных рождений по ведомостям городской управы возрос до 50\% всех рождений, будучи ранее равен $30 \%$. 
В наемные кормилицы в воспитательные дома должны приниматься лишь откормившие или потерявшие своих детей.

Раздача питомцев на воспитание в семьи, кроме прямой необходимости для воспитательных домов, имеет и свои хорошие нравственные стороны, причем желательно практиковать такую раздачу питомцев в возрасте, наиболее старшем, 3-4 месяцев.

Отсутствие гигиенических условий для грудных детей, в равной мере для крестьянских и питомцев, составляет явление, побороть которое может лишь время, грамотность и участие всех интеллигентных лиц, соприкасающихся с крестьянским населением.

Новые правила приема детей в воспитательные дома, не представляя в сущности своей тех необычайных стеснений, которые приписываются им, при ближайшем ознакомлении с ними, со временем должны убавить как недовольство ими, так и вызванное ими подкидывание.

Децентрализация столичных воспитательных домов является необходимым продолжением начатой реформы. 


\section{THE CARE OF CHILDREN IN FOUNDLING HOSPITALS}

\section{NIKOLAI YABLOKOV}

A reprint of the essay of Nikolai Yablokov (1845-1904) published by him in 1901 and awarded an honorable mention at the first competition for the Empress Alexandra Feodorovna Prize. What prompted N.V. Yablokov to write this essay was, among other things, the attention of Emperor Alexander III to the high mortality of children in the foundling hospitals of Moscow and St. Petersburg and, as a result, subsequent significant changes in the rules for the functioning of these institutions (Decree of 1891).

N.V. Yablokov turns his attention first to the history of the attitude of the state and society towards abortion, infanticide and the abandoning of illegitimate children in the period preceding the creation of the first orphanage in Milan in 767, and then looks in detail at the development of foundling hospitals and covert baby boxes ("tours") in Catholic Europe (in Protestant countries, the opening of foundling hospitals was considered immoral).

Most of the essay is devoted to the organization of assistance to orphans and illegitimate children in Russia in orphanages established in churches at first by private initiative, and later by order of Peter I, and finally in the first Foundling hospital established in Moscow in 1763 by a manifesto of Catherine II, and in the second in St. Petersburg in 1771. N. Yablokov draws a detailed picture of the functioning of foundling hospitals, including the rules for and special features of admitting and caring for the children. Special attention is given to the positive and negative aspects of both the open and the covert admission of infants (until 1891, admission to the orphanages was covert).

N.V. Yablokov received his medical degree from the Medical Department of Moscow University, worked as a doctor in the nursing sections of the Moscow Foundling hospital and as chief physician in the Sofia Children's Hospital (now the N.F. Filatov Children's City Clinical Hospital No. 13), and was actively engaged in organizational issues related to the protection of children's health and social welfare.

Keywords: foundling hospital, orphans, illegitimate children, foundlings, infant mortality.

\section{NIKOLAY YABLOKOV (1845-1904).}

YABLOKOV N.V. (1901). THE CARE OF CHILDREN IN FOUNDLING HOSPITALS // TRUDOVAYA POMOSHCH' [LABOR ASSISTANCE"]: MAY, APRIL AND JUNE. 